\title{
Supplementary Material for "Contribution of the world's main dust source regions to the global cycle of desert dust"
}

\author{
J. F. Kok ${ }^{1, *}$, A. A. Adebiyi ${ }^{1}$, S. Albani ${ }^{2,3}$, Y. Balkanski ${ }^{3}$, R. Checa-Garcia ${ }^{3}$, M. Chin ${ }^{4}$, P. R. Colarco ${ }^{4}$, D. S. \\ Hamilton $^{5}$, Y. Huang ${ }^{1}$, A. Ito ${ }^{6}$, M. Klose ${ }^{7}$, L. Li ${ }^{5}$, N. M. Mahowald ${ }^{5}$, R. L. Miller ${ }^{8}$, V. Obiso ${ }^{7,8}$, C. Pérez \\ García-Pando $^{7,9}$, A. Rocha-Lima ${ }^{10,11}$, and J. S. Wan ${ }^{5}$ \\ ${ }^{1}$ Department of Atmospheric and Oceanic Sciences, University of California, Los Angeles, CA 90095, \\ USA \\ ${ }^{2}$ Department of Environmental and Earth Sciences, University of Milano-Bicocca, Milano, Italy \\ ${ }^{3}$ Laboratoire des Sciences du Climat et de l'Environnement, CEA-CNRS-UVSQ-UPSaclay, Gif-sur- \\ Yvette, France \\ ${ }^{4}$ Atmospheric Chemistry and Dynamics Laboratory, NASA Goddard Space Flight Center, Greenbelt, MD \\ 20771, USA \\ ${ }^{5}$ Department of Earth and Atmospheric Sciences, Cornell University, Ithaca, NY 14850, USA \\ ${ }^{6}$ Yokohama Institute for Earth Sciences, JAMSTEC, Yokohama, Kanagawa 236-0001, Japan \\ ${ }^{7}$ Barcelona Supercomputing Center (BSC), 08034 Barcelona, Spain \\ ${ }^{8}$ NASA Goddard Institute for Space Studies, New York NY10025 USA \\ ${ }^{9}$ ICREA, Catalan Institution for Research and Advanced Studies, 08010 Barcelona, Spain \\ ${ }^{10}$ Physics Department, UMBC, Baltimore, Maryland, USA \\ ${ }^{11}$ Joint Center Joint Center for Earth Systems Technology, UMBC, Baltimore, Maryland, USA \\ *e-mail: jfkok@ucla.edu
}




\section{Supplementary Materials}

This document contains a description of how results of the seasonal dust emission, loading, and DAOD per source region were obtained from AeroCom Phase I simulations. This document also contains a number of Supplementary Figures, which are summarized below:

- Figures S1-S4. Fractional contribution of each source region to the global dust cycle in respectively boreal Winter (DJF), Spring (MAM), Summer (JJA), and Fall (SON).

- Figure S5. Annual size-resolved lifetime of dust emitted from each of the nine source regions, as simulated by the six models in the model ensemble.

- Figures S6-S9. Size-resolved lifetime of dust emitted from each of the nine source regions in respectively Winter, Spring, Summer, and Fall.

- Figure S10. The column-integrated bulk mass extinction efficiency $\left(\mathrm{m}^{2} / \mathrm{g}\right)$ due to dust from all source regions.

- Figure S11. Attribution of the annually averaged PM20 dust loading to the world's main source regions.

- Figures S12-S15. Attribution of the 2D dust aerosol optical depth in respectively boreal Winter (DJF), Spring (MAM), Summer (JJA), and Fall (SON) to the world's main source regions.

- Figures S16-S19. Attribution of the 2D dust column loading in respectively boreal Winter (DJF), Spring (MAM), Summer (JJA), and Fall (SON) to the world's main source regions.

- Figures S20-S23. Attribution of the zonally averaged dust concentration to the world's main source regions in respectively boreal Winter (DJF), Spring (MAM), Summer (JJA), and Fall (SON).

- Figure S24. Map of regions to which deposition fluxes are quantified in the main text.

- Figure S25-28. Attribution to the world's main source regions of the seasonally-averaged PM20 dust deposition flux in respectively boreal Winter (DJF), Spring (MAM), Summer (JJA), and Fall (SON).

\section{Analysis of seasonal dust cycle in AeroCom simulations}

We obtain estimates of the seasonally-averaged dust loading $\left(\tilde{L}_{r, s}^{\text {Aer }}\right)$ and DAOD $\left(\tilde{\tau}_{r, s}^{\text {Aer }}\right)$ for each of the models in the AeroCom Phase I ensemble by following the procedure in Section 2.2 of the main text. That is,

$$
\begin{gathered}
\tilde{L}_{r, s}^{\text {Aer }}=\tilde{F}_{r, s}^{\text {Aer }} \tilde{T}_{\text {glob }}^{\text {Aer }} \frac{\breve{T}_{r, s}}{\breve{T}_{\text {glob }}} \text {, and } \\
\tilde{\tau}_{r, s}^{\text {Aer }}=\frac{\tilde{L}_{r, s}^{\text {Aer }}}{A_{\text {Earth }}} \tilde{\epsilon}_{\text {glob }}^{\text {Aer }} \frac{\breve{\epsilon}_{r, s}}{\breve{\epsilon}_{\text {glob }}},
\end{gathered}
$$

where $\breve{\boldsymbol{T}}_{\boldsymbol{r}, \boldsymbol{s}}$ and $\breve{\boldsymbol{\epsilon}}_{\boldsymbol{r}, \boldsymbol{s}}$ are respectively the bulk lifetime for source region $r$ and season $s$, obtained from our analysis. 


\section{Supplementary Figures}
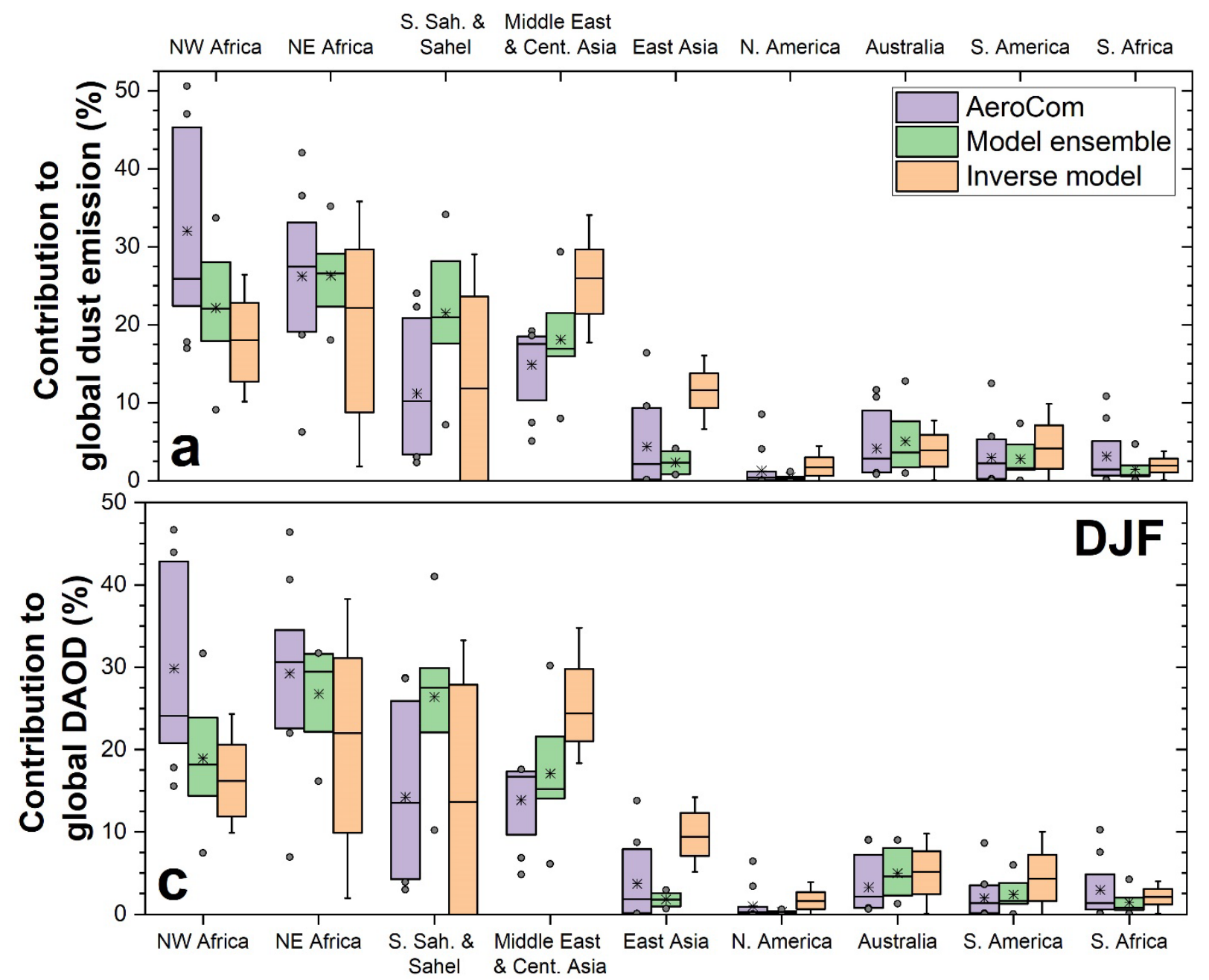

Figure S1. Fractional contribution of each source region to the global dust cycle in boreal Winter (DJF). Shown are the fractional contributions to the global dust emission (and deposition) flux (a), the global dust loading (b), and the global dust aerosol optical depth (c). Box boundaries approximately denote the one standard error range (i.e., contains 9 out of 13 AeroCom simulations, 4 out of 6 model ensemble members, and $68 \%$ probability range for the inverse model's results), gray circles denote the individual simulation results outside of this range, whiskers denote the $95 \%$ confidence interval for the inverse model's results, horizontal solid lines denote the median result, and stars denote the mean result. 

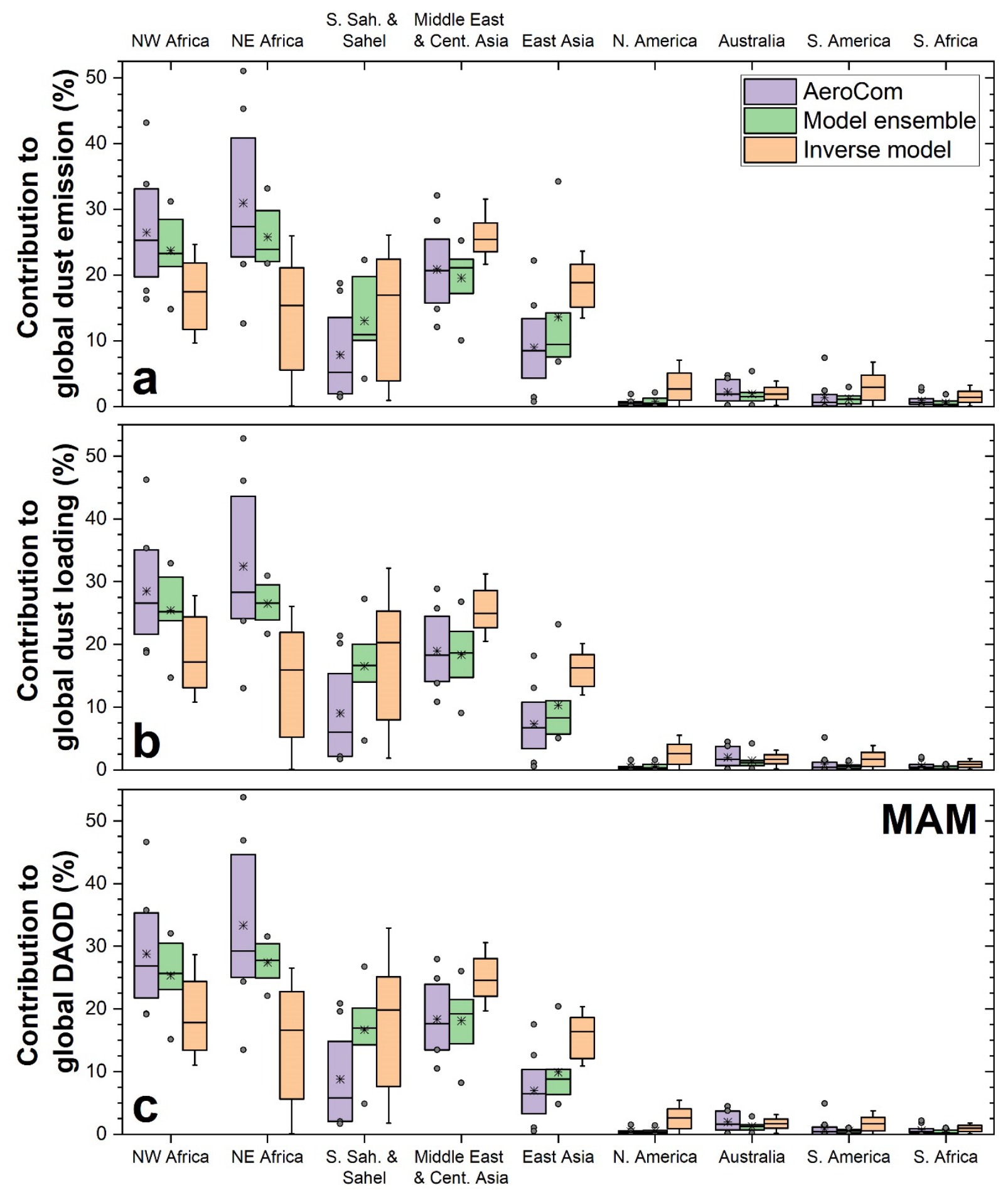

Figure S2. As in Figure S1, but for the fractional contribution of each source region to the global dust cycle in boreal Spring (DJF). 

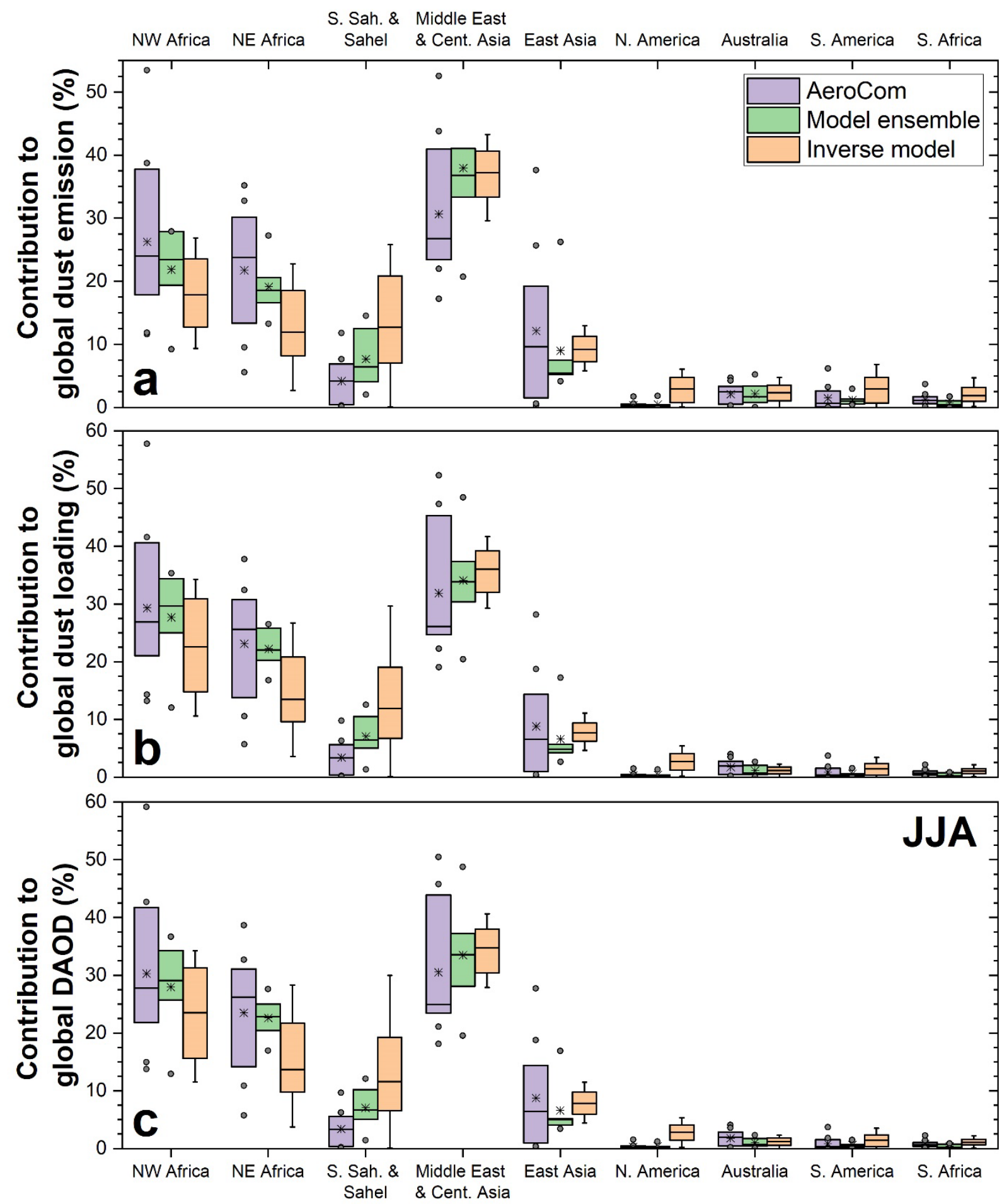

Figure S3. As in Figure S1, but for the fractional contribution of each source region to the global dust cycle in boreal Summer (JJA). 

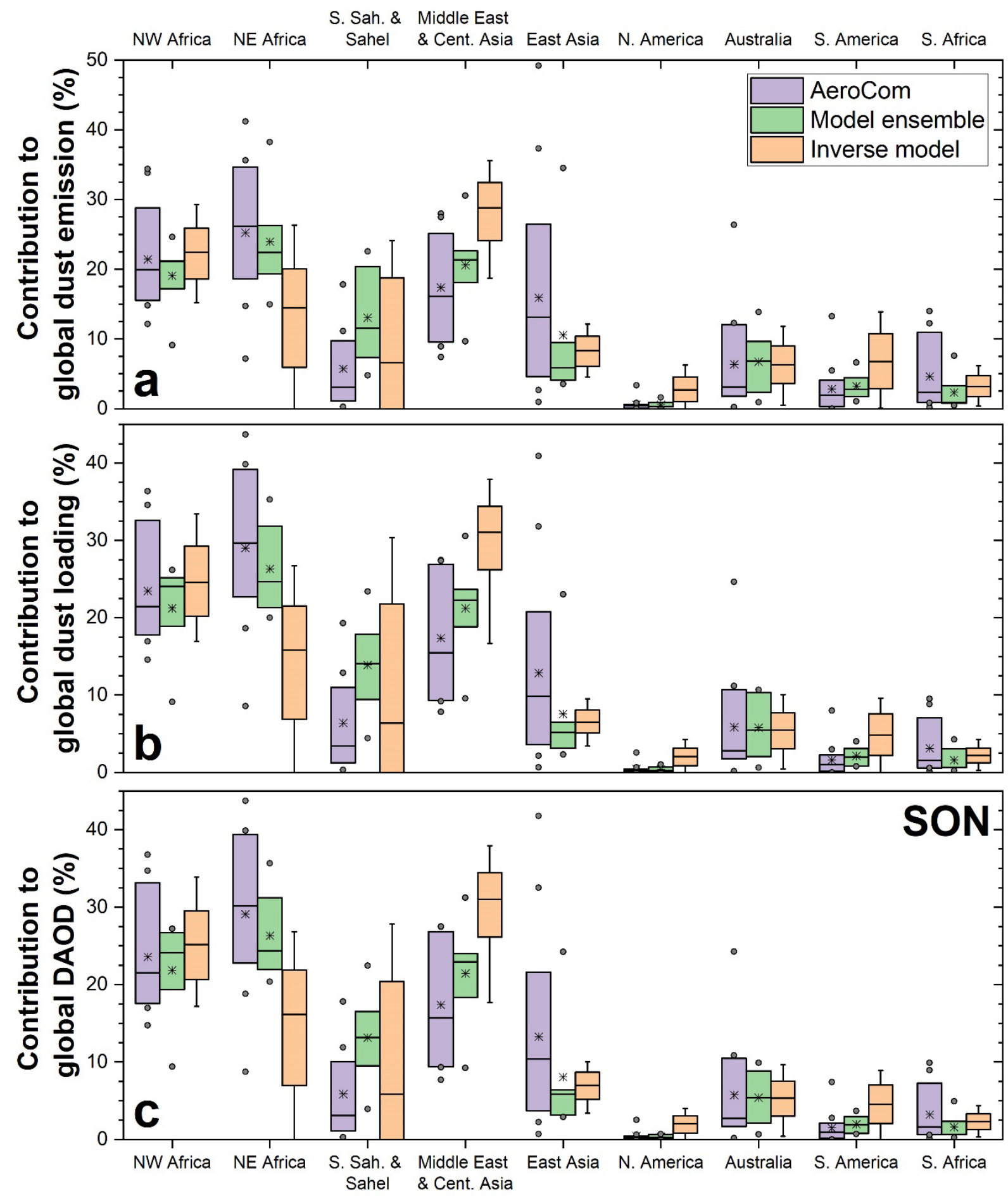

Figure S4. As in Figure S1, but for the fractional contribution of each source region to the global dust cycle in boreal Fall (SON). 
Annual
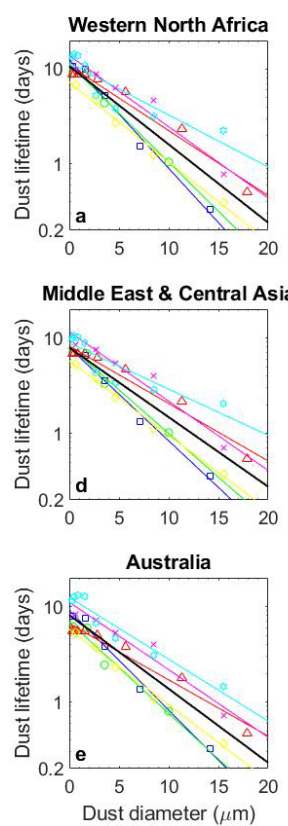

Eastern North Africa
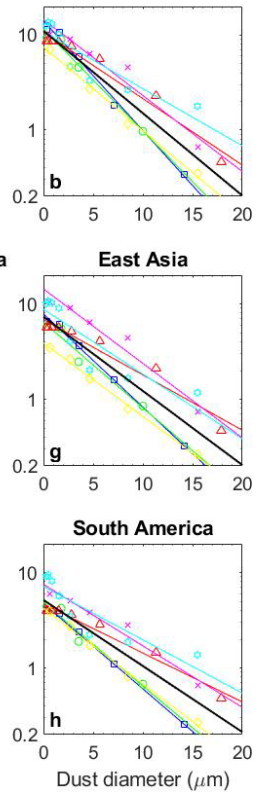
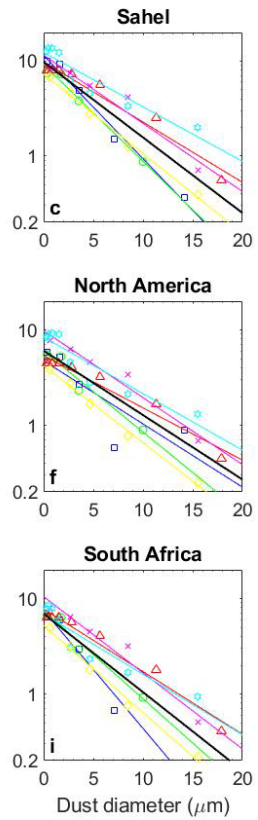

Annual

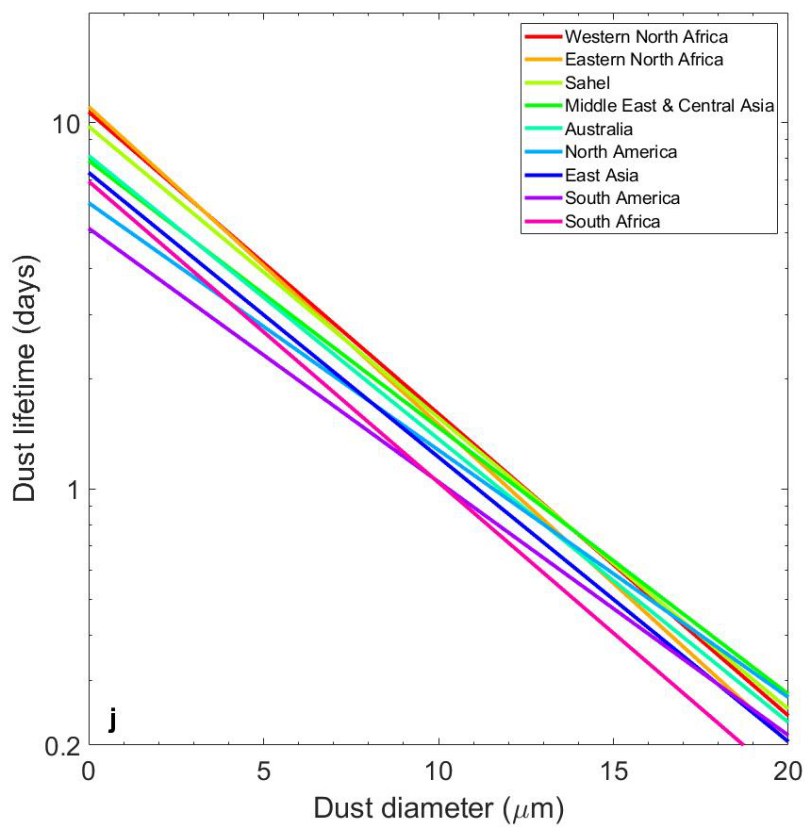

Figure S5. Annual size-resolved lifetime of dust emitted from each of the nine source regions, as simulated by the six models in the model ensemble $(\mathrm{CESM}=$ blue squares; IMPACT $=$ green circles; GISS = red triangles; GOCART $=$ purple crosses; MONARCH $=$ cyan hexagons; INCA = yellow diamonds). Also shown are the Maximum Likelihood Estimates (MLE) of the best fit for each region (black lines), which uses data from all the models and were obtained as described in the Supplement to Kok et al. (2017). To facilitate comparisons between source regions, panel (j) shows the MLEs of the size-resolved lifetime for the nine regions.

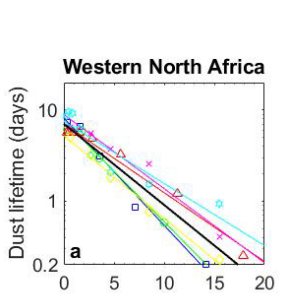

\section{Winter}
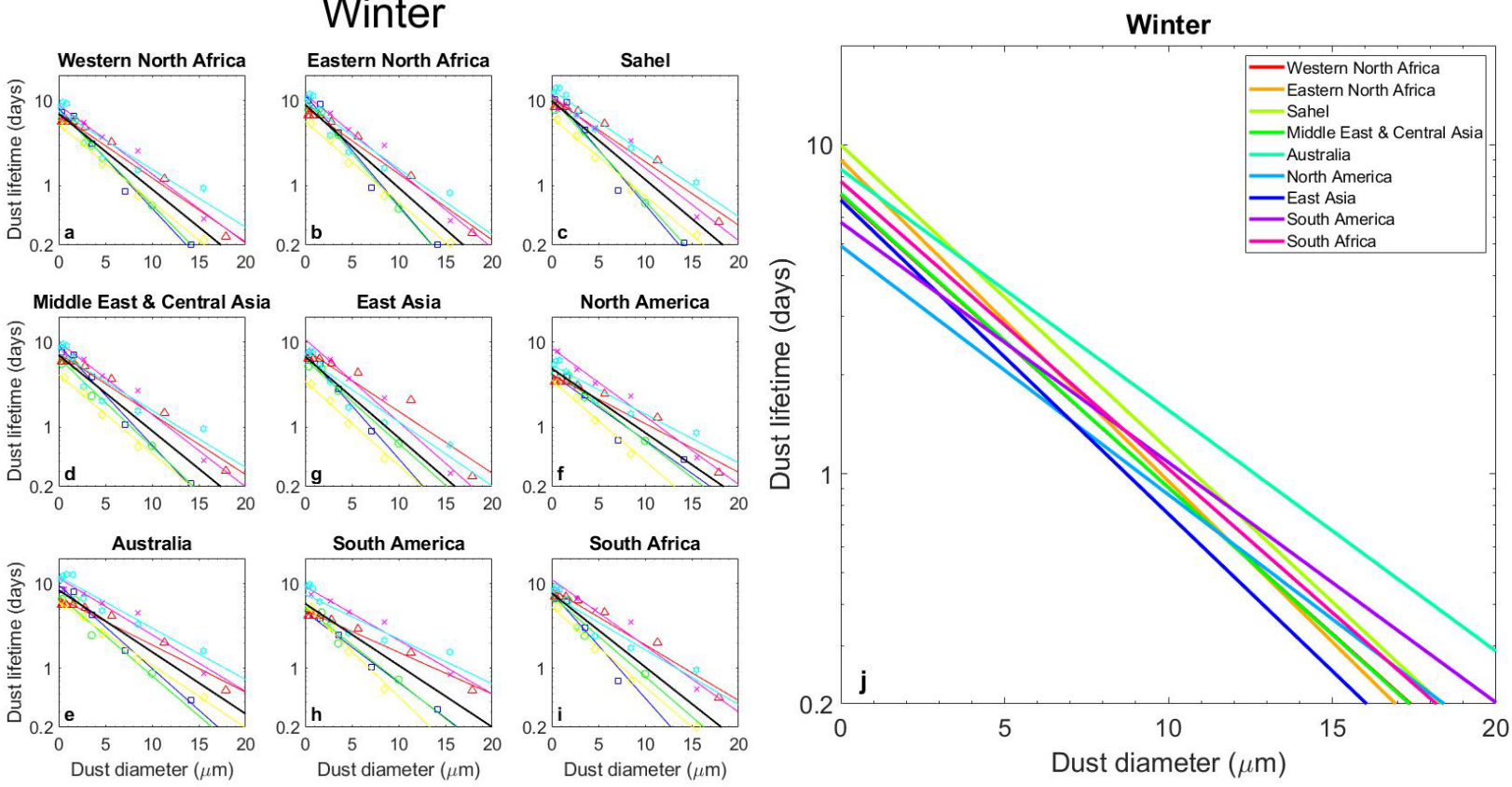

Figure S6. Size-resolved lifetime of dust emitted from each of the nine source regions in Winter (December February for Northern Hemisphere sources; June - August for Southern Hemisphere sources), as simulated by the six models in the model ensemble (CESM = blue squares; IMPACT $=$ green circles; GISS $=$ red triangles; GOCART 
$=$ purple crosses; $\mathrm{MONARCH}=$ cyan hexagons; $\mathrm{INCA}=$ yellow diamonds). Also shown are the Maximum Likelihood Estimates (MLE) of the best fit for each region (black lines), which uses data from all the models and were obtained as described in the Supplement to Kok et al. (2017). To facilitate comparisons between source regions, panel (j) shows the MLEs of the size-resolved lifetime for the nine regions.

\section{Spring}
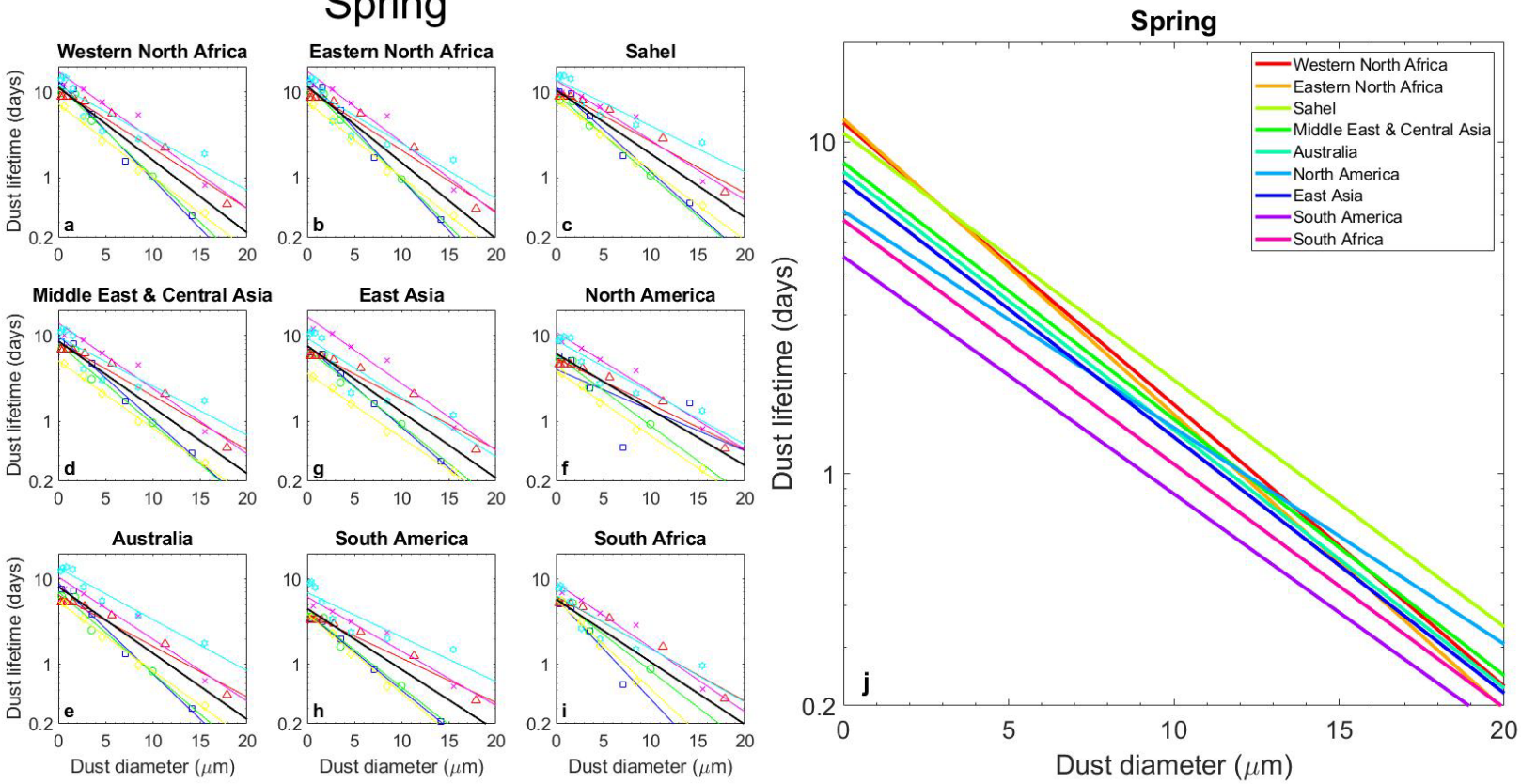

Figure S7. As in Figure S6, but for the size-resolved dust lifetime in Spring (March - May for Northern Hemisphere sources; September - November for Southern Hemisphere sources).
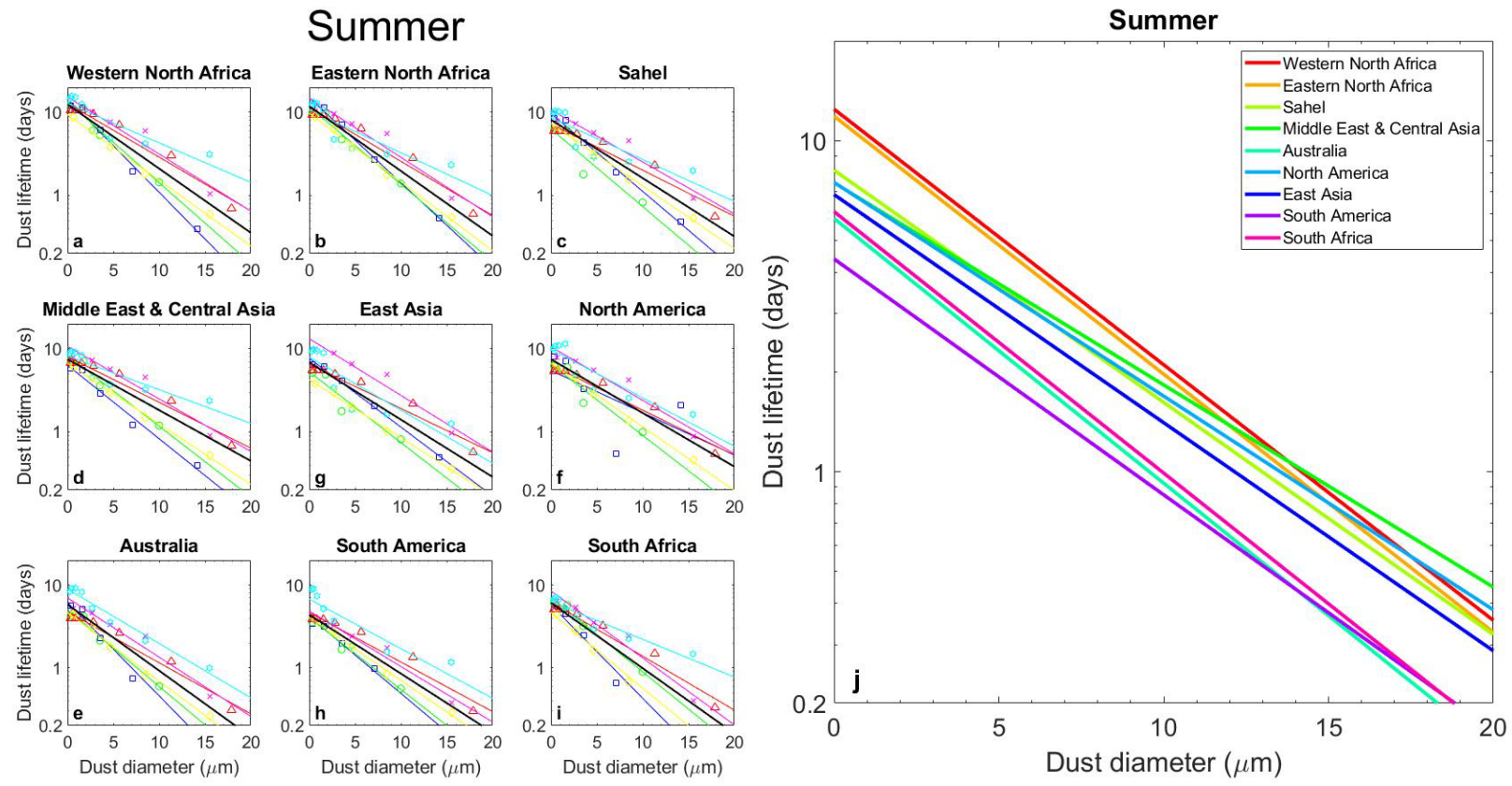

Figure S8. As in Figure S6, but for the size-resolved dust lifetime in Spring (March - May for Northern Hemisphere sources; September - November for Southern Hemisphere sources). 
Fall
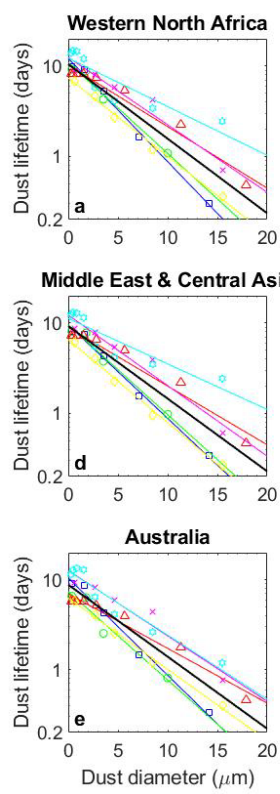
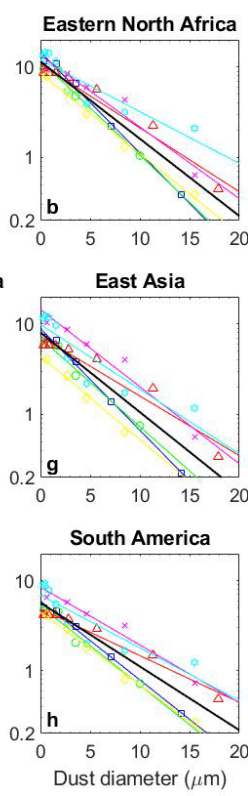
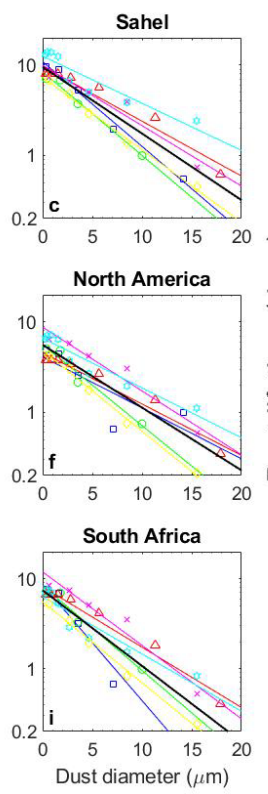

Fall

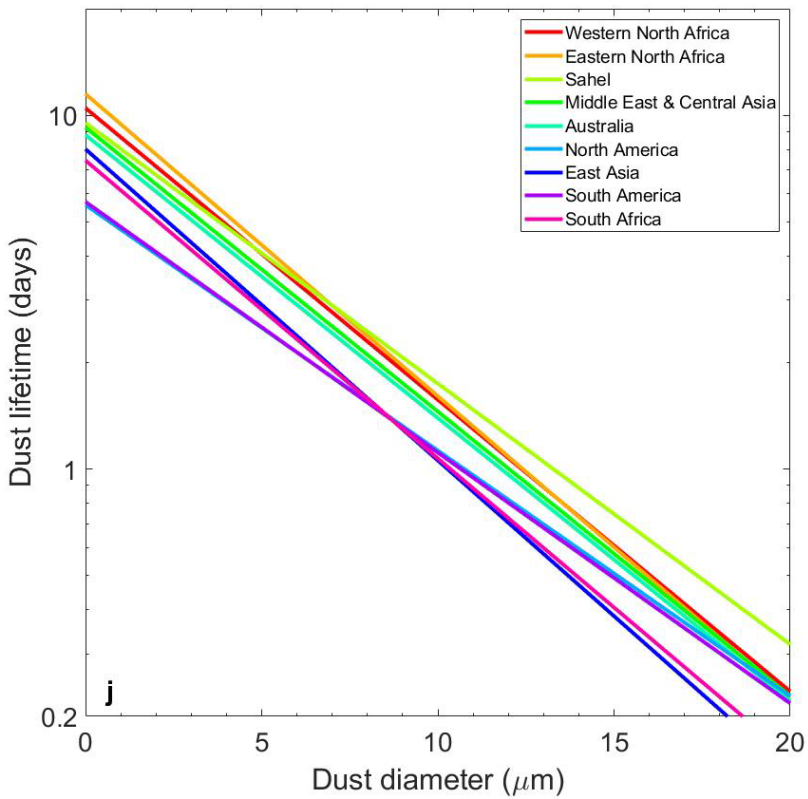

Figure S9. As in Figure S6, but for the size-resolved dust lifetime in Spring (March - May for Northern Hemisphere sources; September - November for Southern Hemisphere sources).

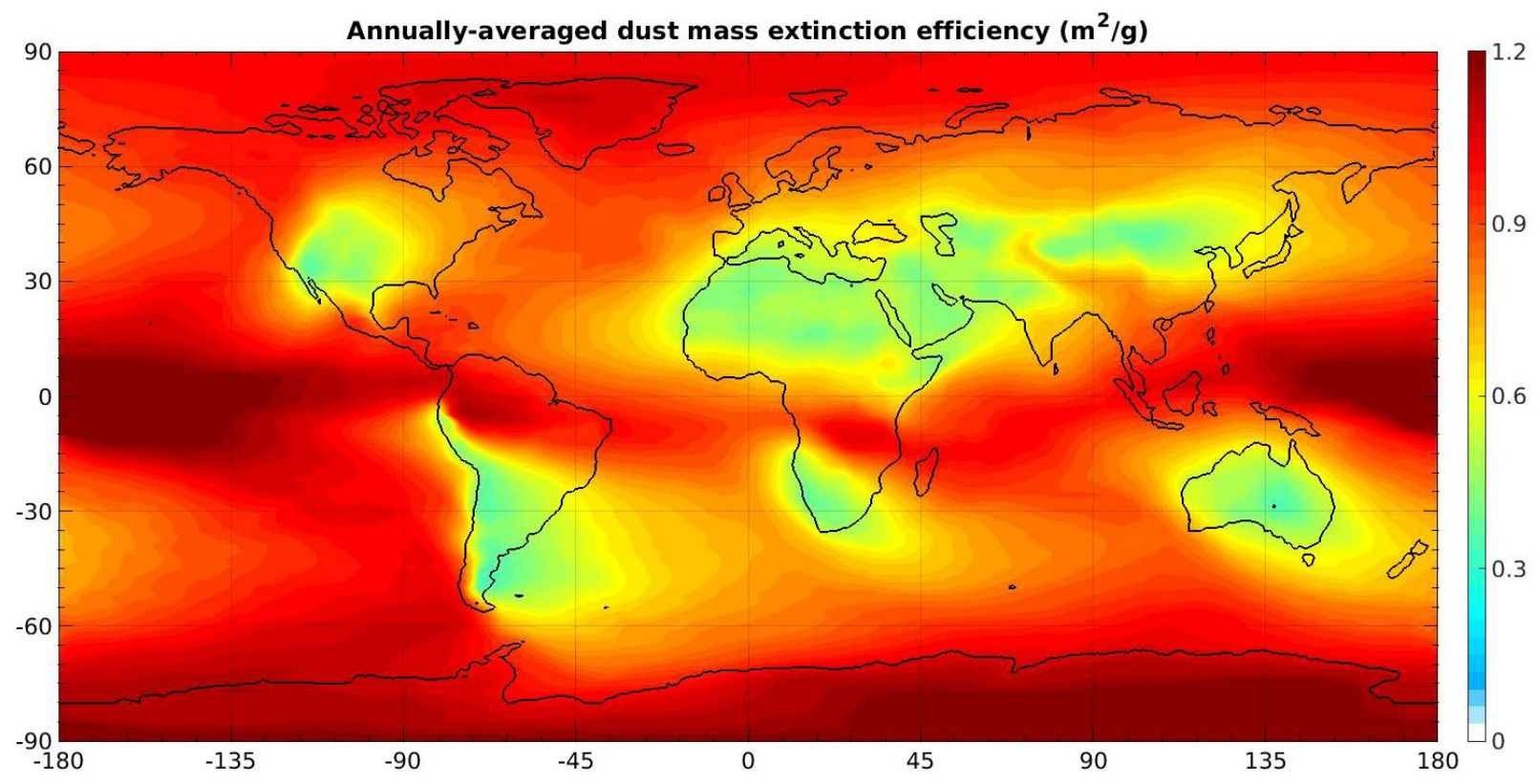

Figure S10. The column-integrated bulk mass extinction efficiency $\left(\mathrm{m}^{2} / \mathrm{g}\right)$ due to dust from all source regions. 

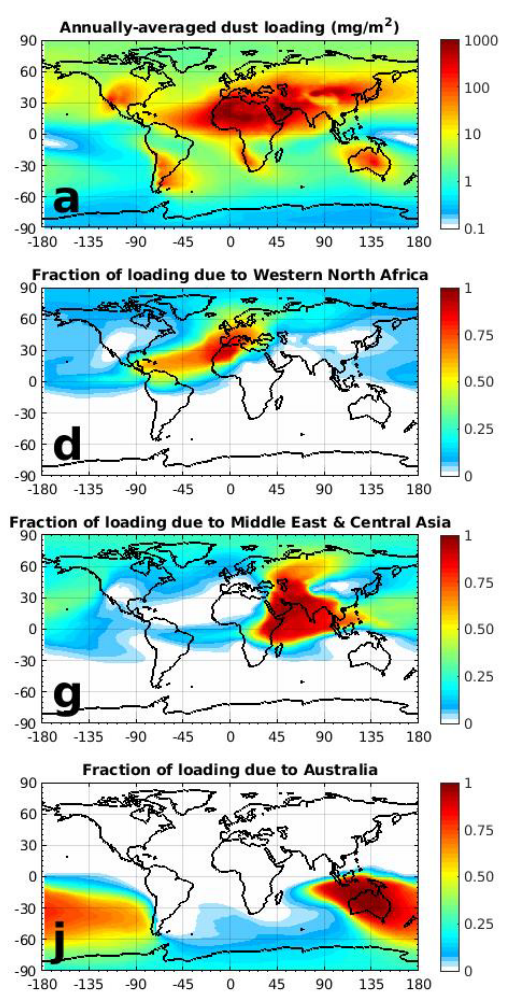
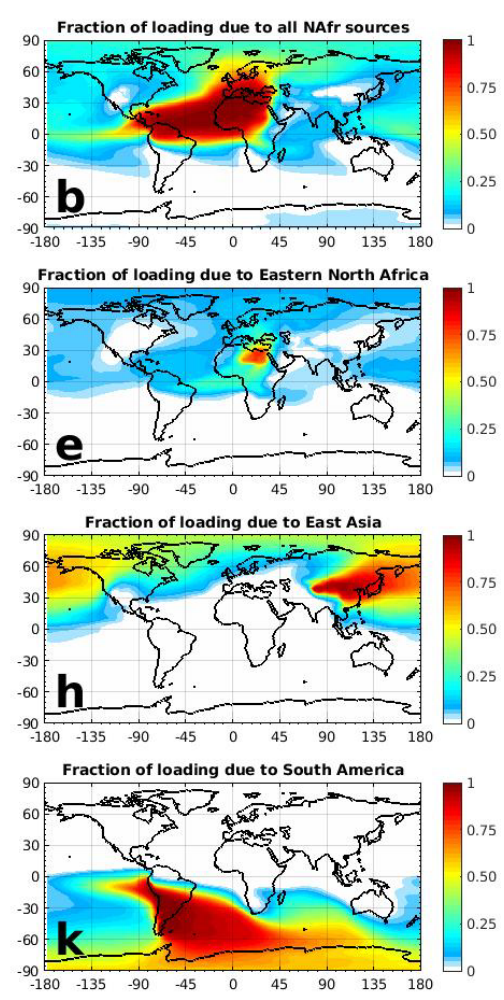
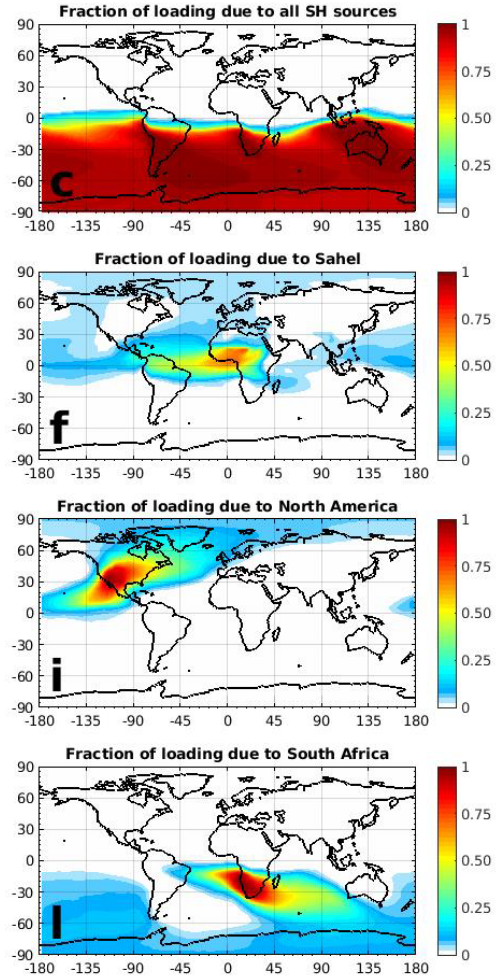

Figure S11. Attribution of the annually averaged $\mathrm{PM}_{20}$ dust loading to the world's main source regions. Panel ordering is identical to Figure 5 and the seasonally resolved attribution of dust loading is shown in Figures S15-S18.

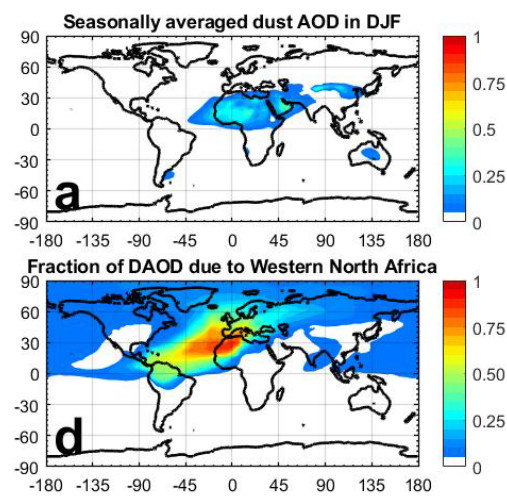

Fraction of DAOD due to Middle East \& Central Asia
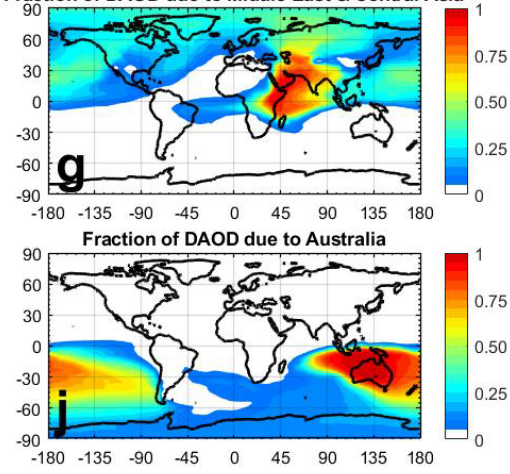

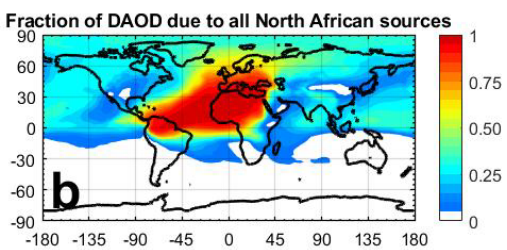

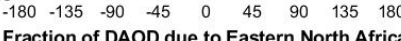
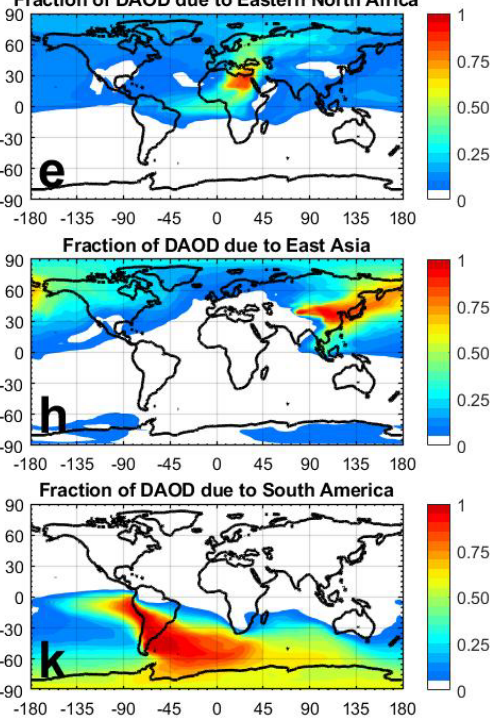

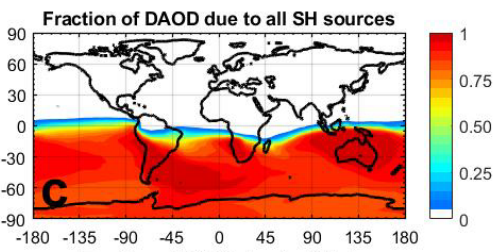

Fraction of DAOD due to Sahel
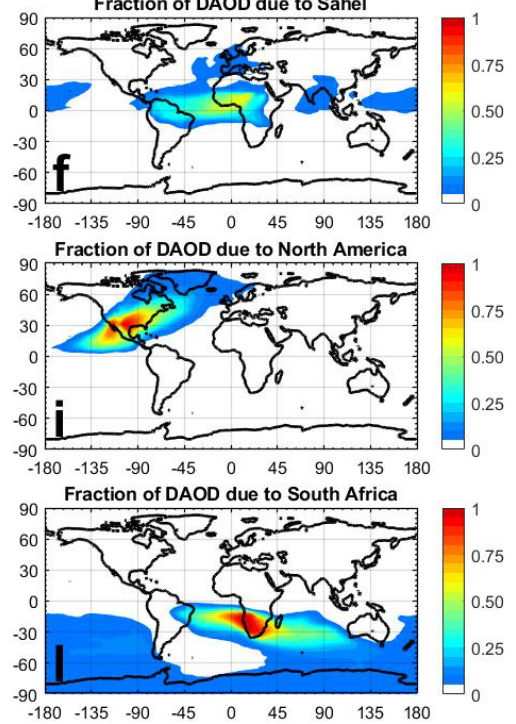

Figure S12. Attribution of the 2D dust aerosol optical depth in boreal winter (DJF) to the world's main source regions. Shown first is the seasonally-averaged DAOD produced from all source regions combined (a), followed by 
the fraction of DAOD that is due to Northern Hemisphere (b) and North African (c) sources. The fraction of DAOD due to each of the three North African source regions are shown in panels (d)-(f), and the fraction of DAOD due to the other three Northern Hemisphere source regions of Middle East \& Central Asia, East Asia, and North America are showns in panels (g)-(i). Finally, the fraction of 2D DAOD due to the three Southern Hemisphere source regions of Australia, South America, and South Africa are shown in panels (j)-(l).
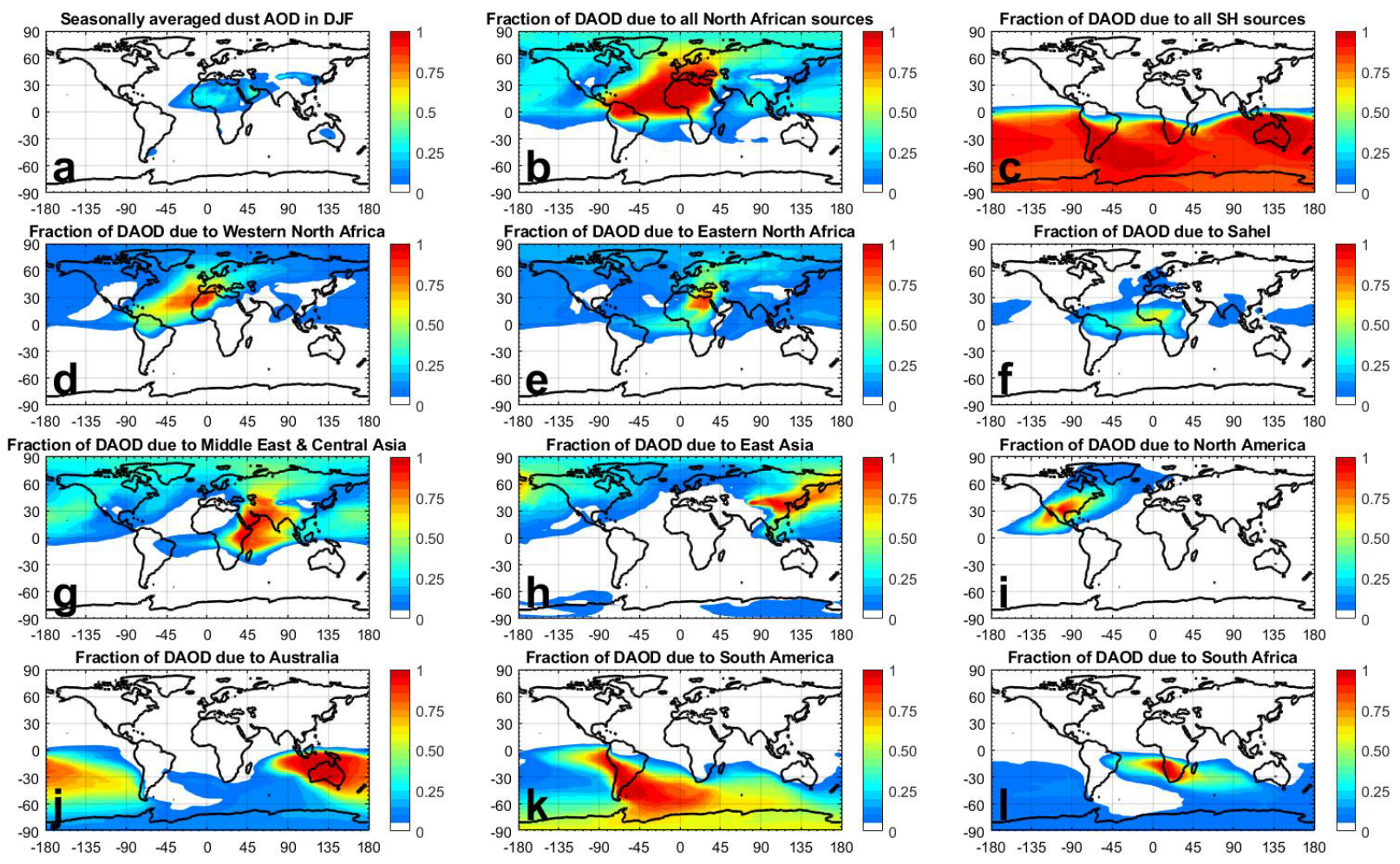

Figure S13. As in Figure S12, but for the attribution of the 2D dust aerosol optical depth in boreal Spring (MAM). 

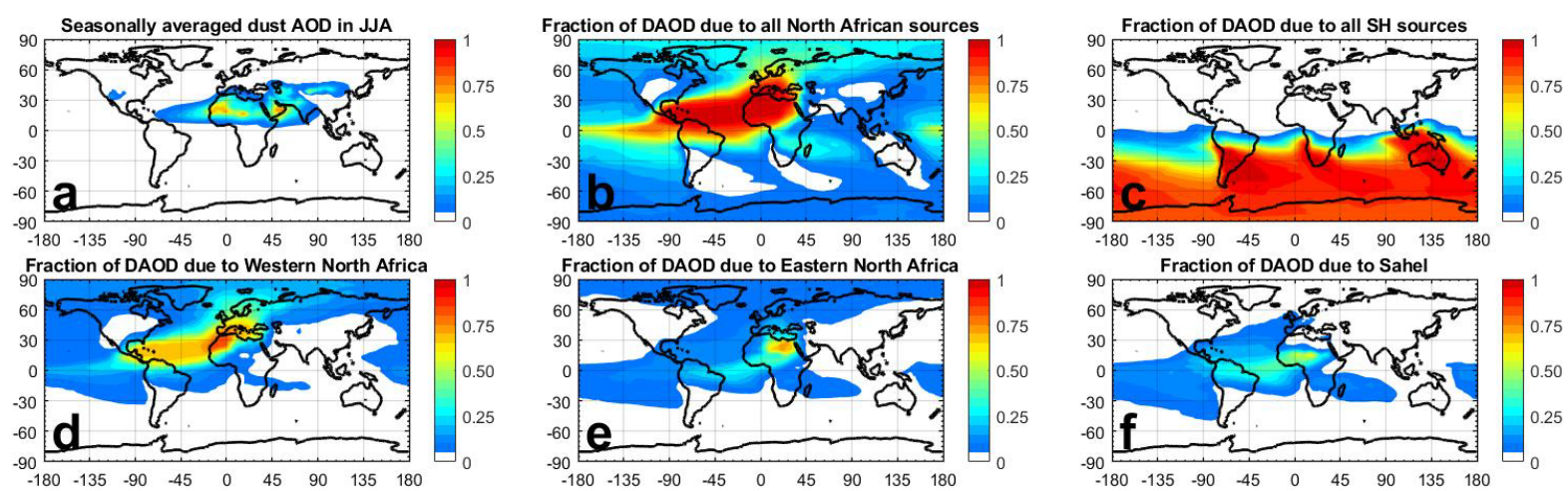

Fraction of DAOD due to Middle East \& Central Asia
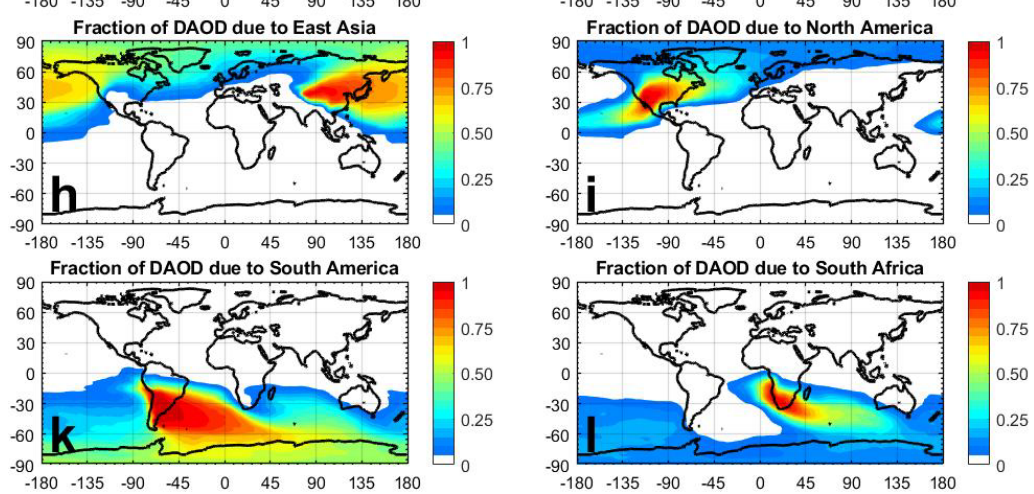

Figure S14. As in Figure S12, but for the attribution of the 2D dust aerosol optical depth in boreal Summer (JJA).
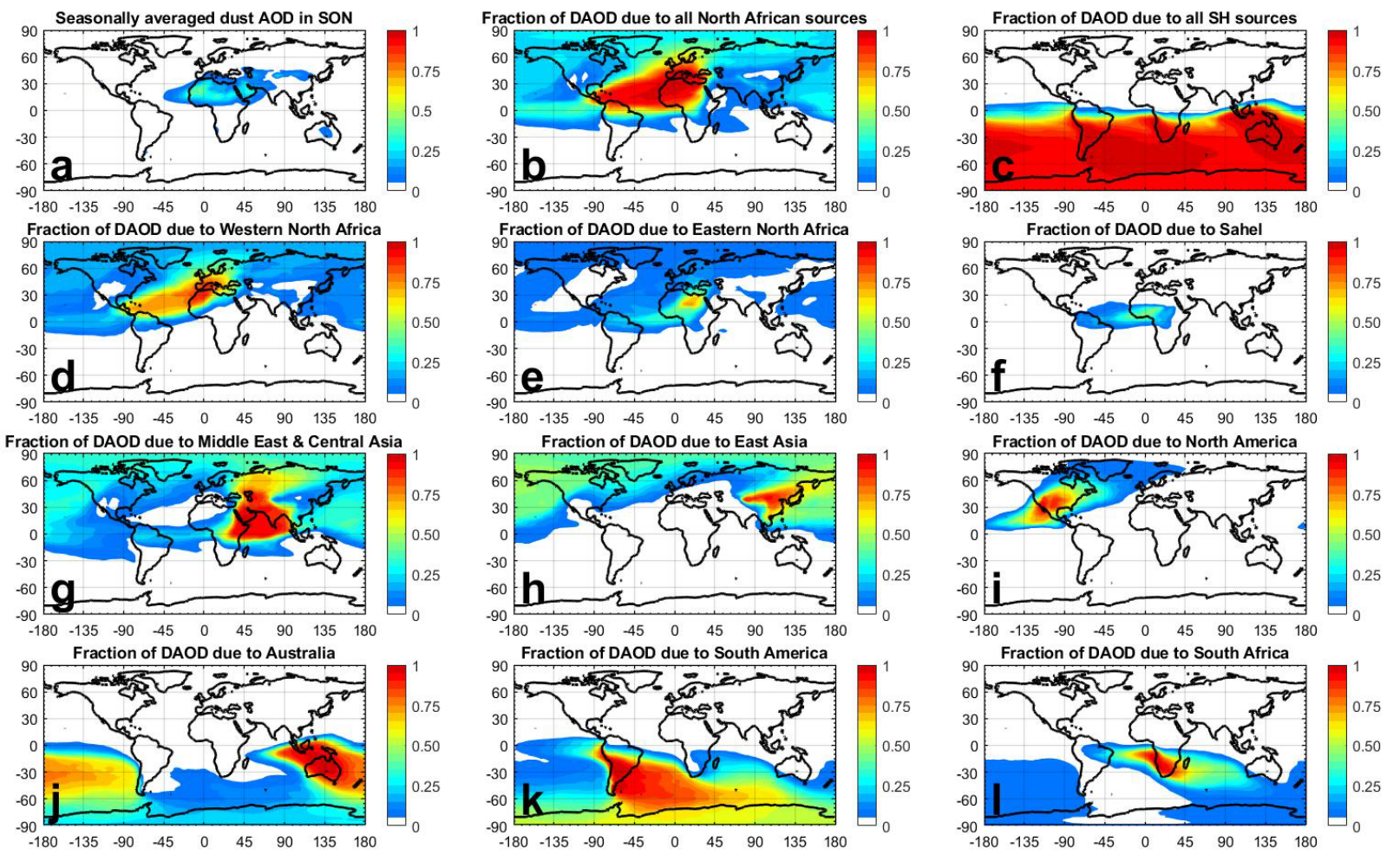

Figure S15. As in Figure S12, but for the attribution of the 2D dust aerosol optical depth in boreal Fall (SON). 


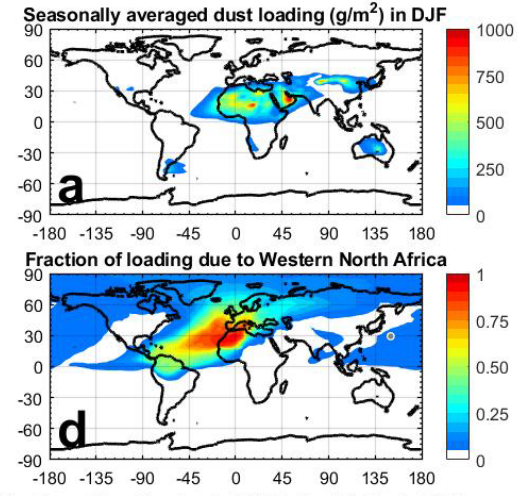

Fraction of loading due to Middle East \& Central Asia
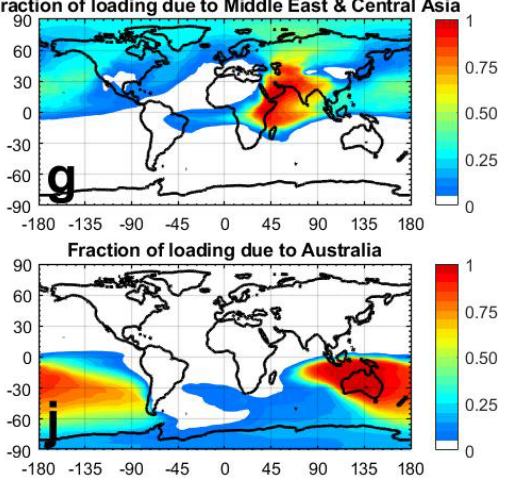
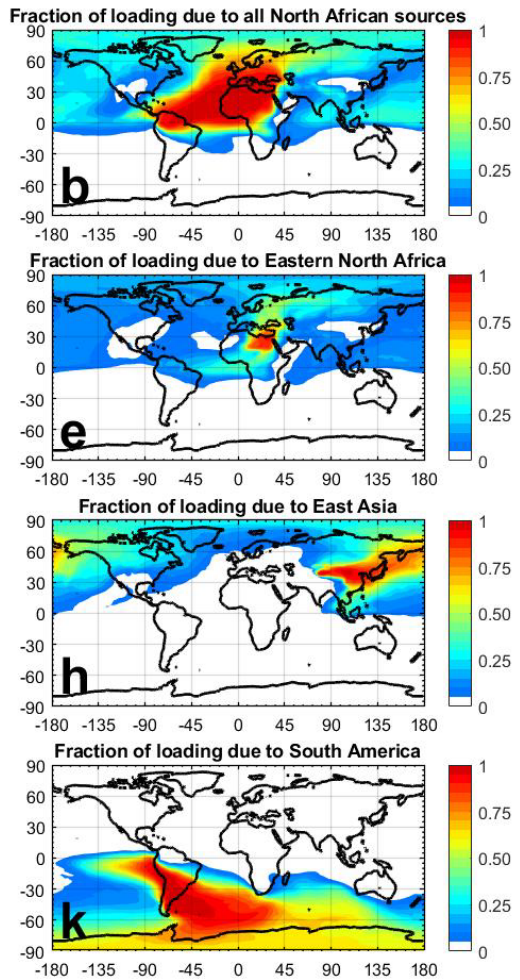

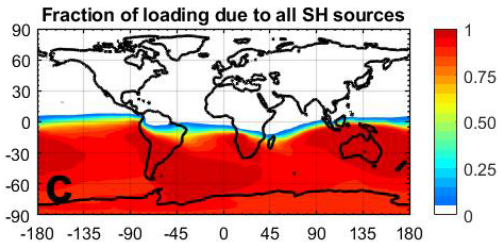

Fraction of loading due to Sahel
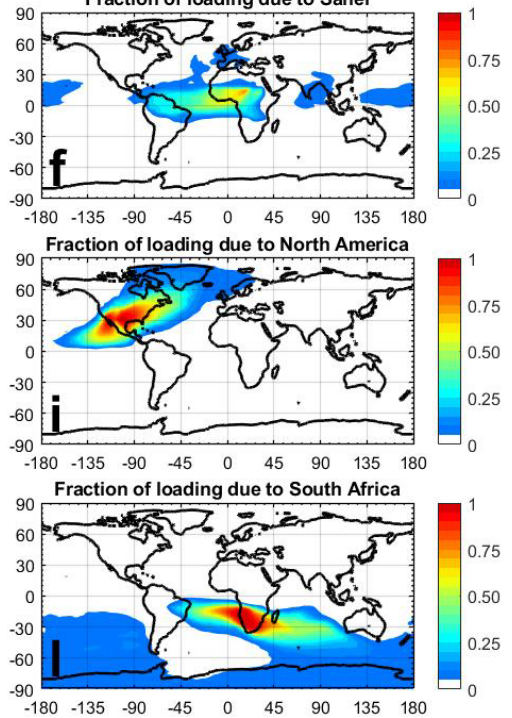

Figure S16. Attribution of the seasonally-averaged $\mathrm{PM}_{20}$ dust loading to the world's main source regions in boreal Winter (DJF). Panel ordering is identical to Figures S12-S15.

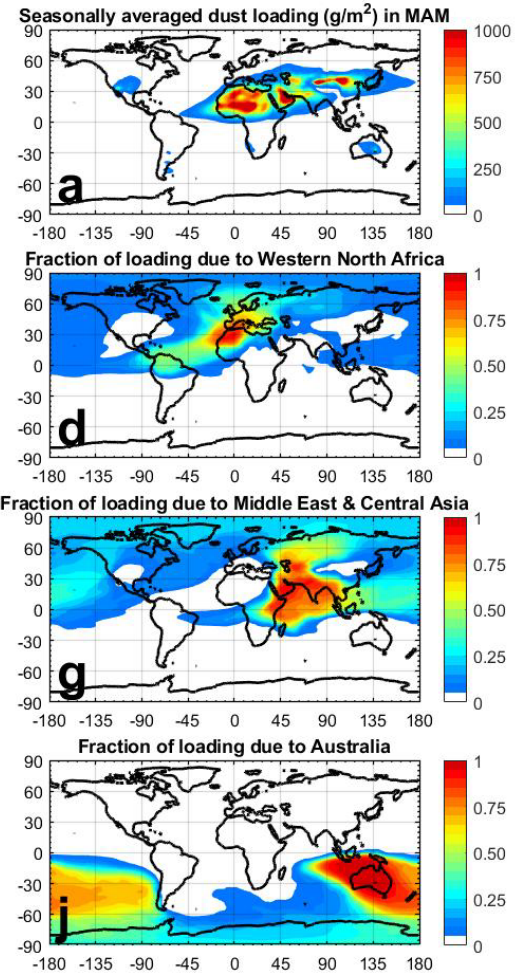

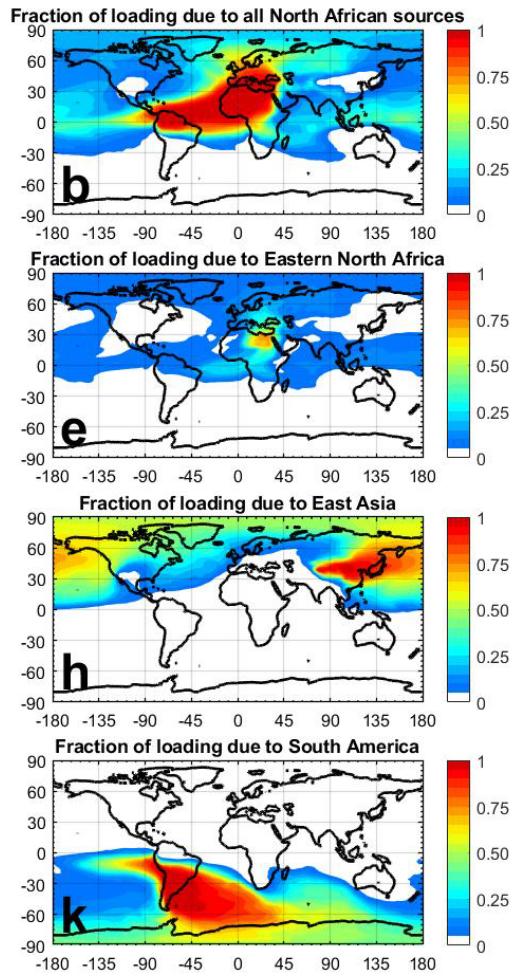

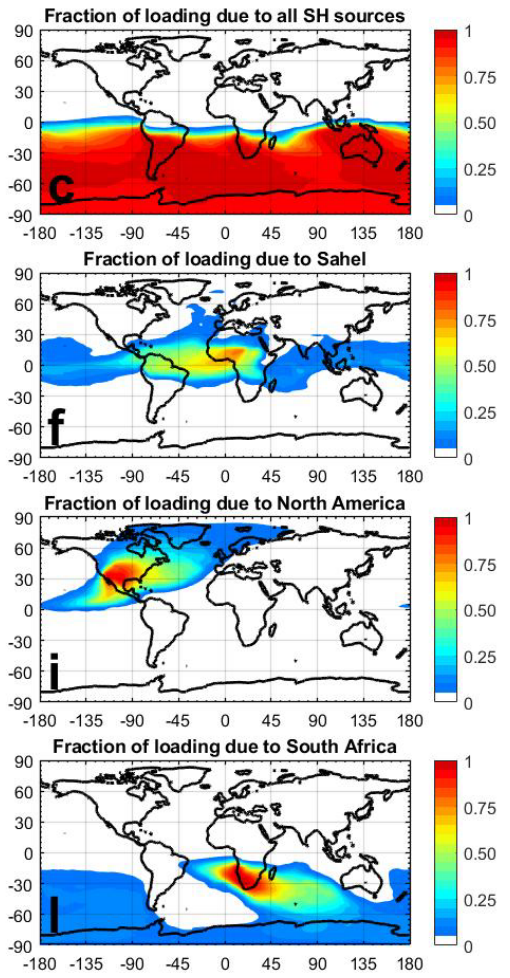


Figure S17. As in Figure S16, but for the attribution of the $\mathrm{PM}_{20}$ dust loading in boreal Spring (MAM).
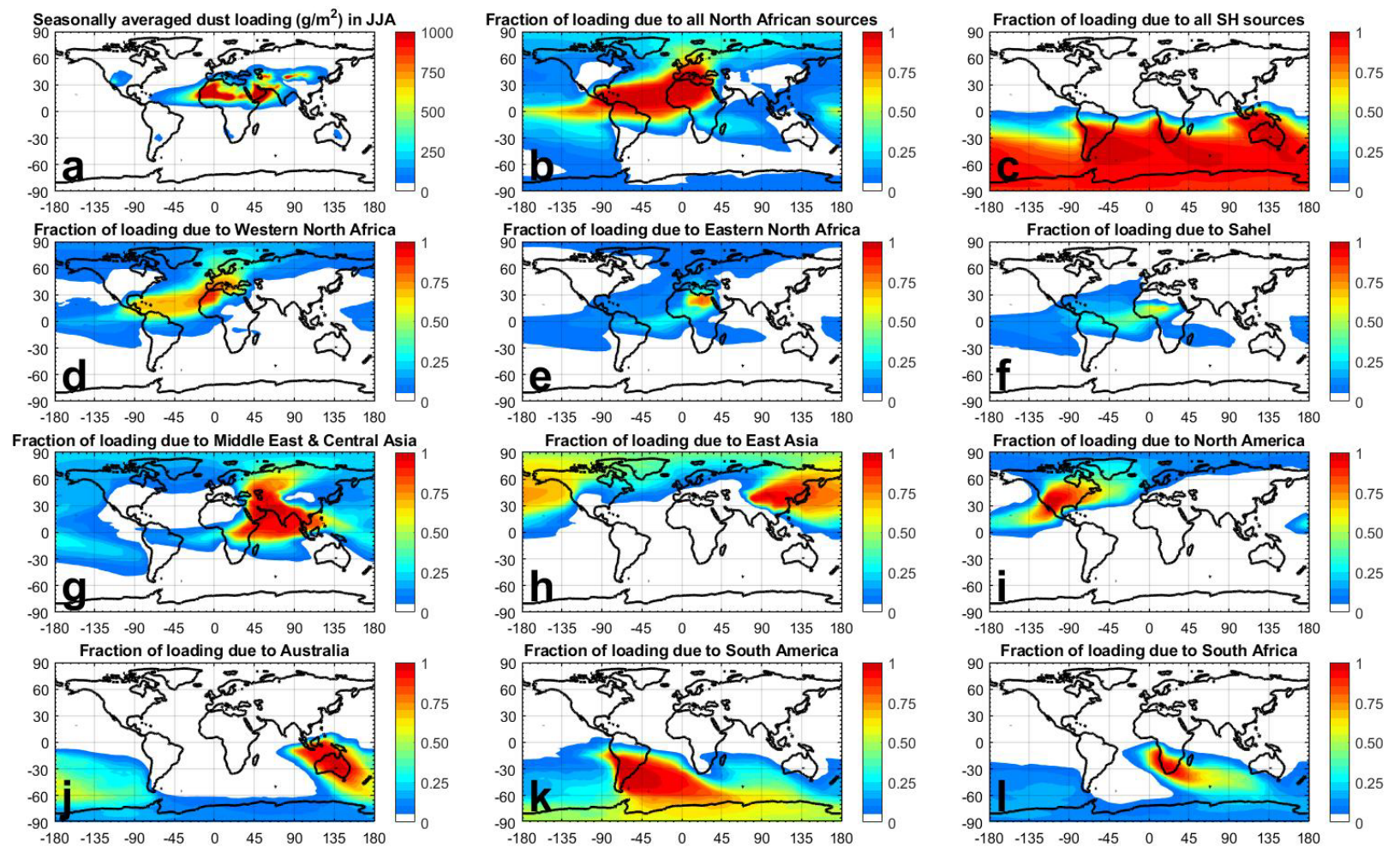

Figure S18. As in Figure S16, but for the attribution of the $\mathrm{PM}_{20}$ dust loading in boreal Summer (JJA). 


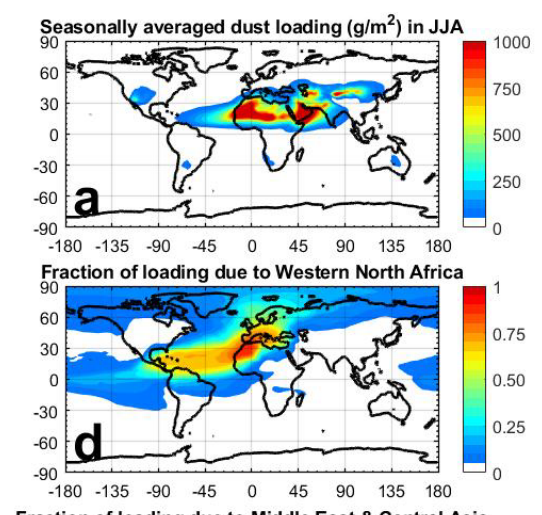

Fraction of loading due to Middle East \& Central Asia
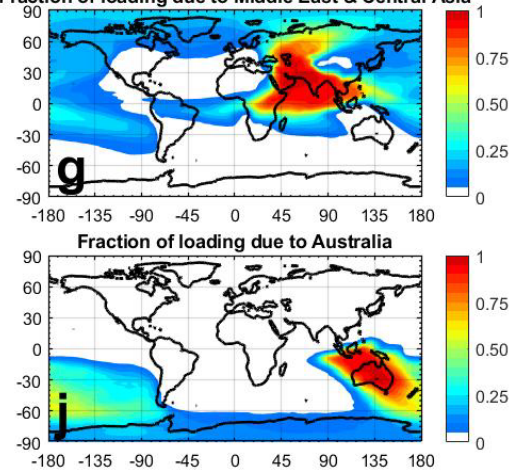
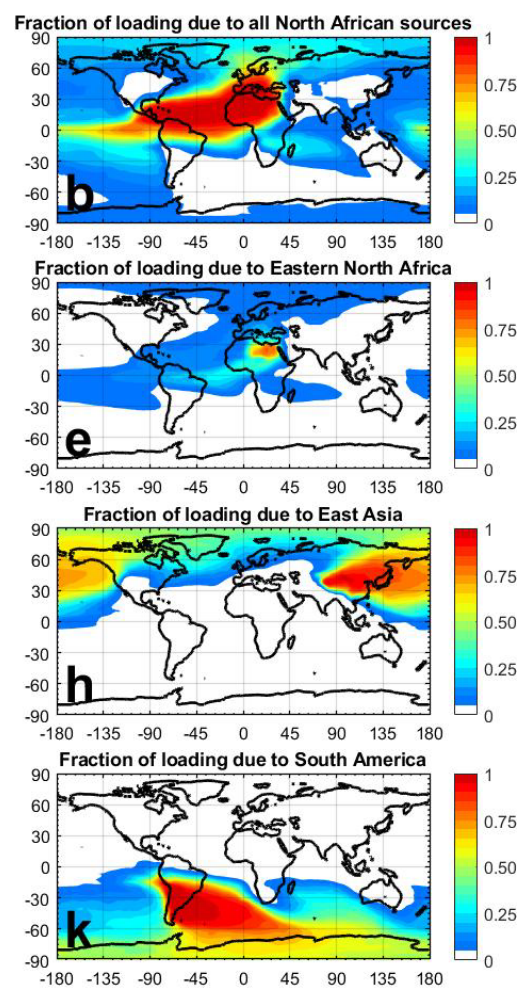
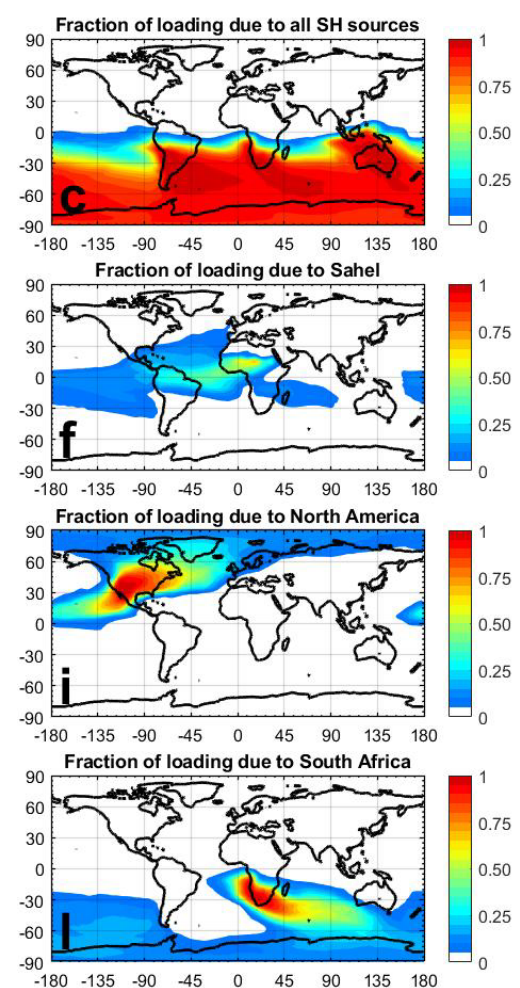

Figure S19. As in Figure S16, but for the attribution of the $\mathrm{PM}_{20}$ dust loading in boreal Fall (SON).
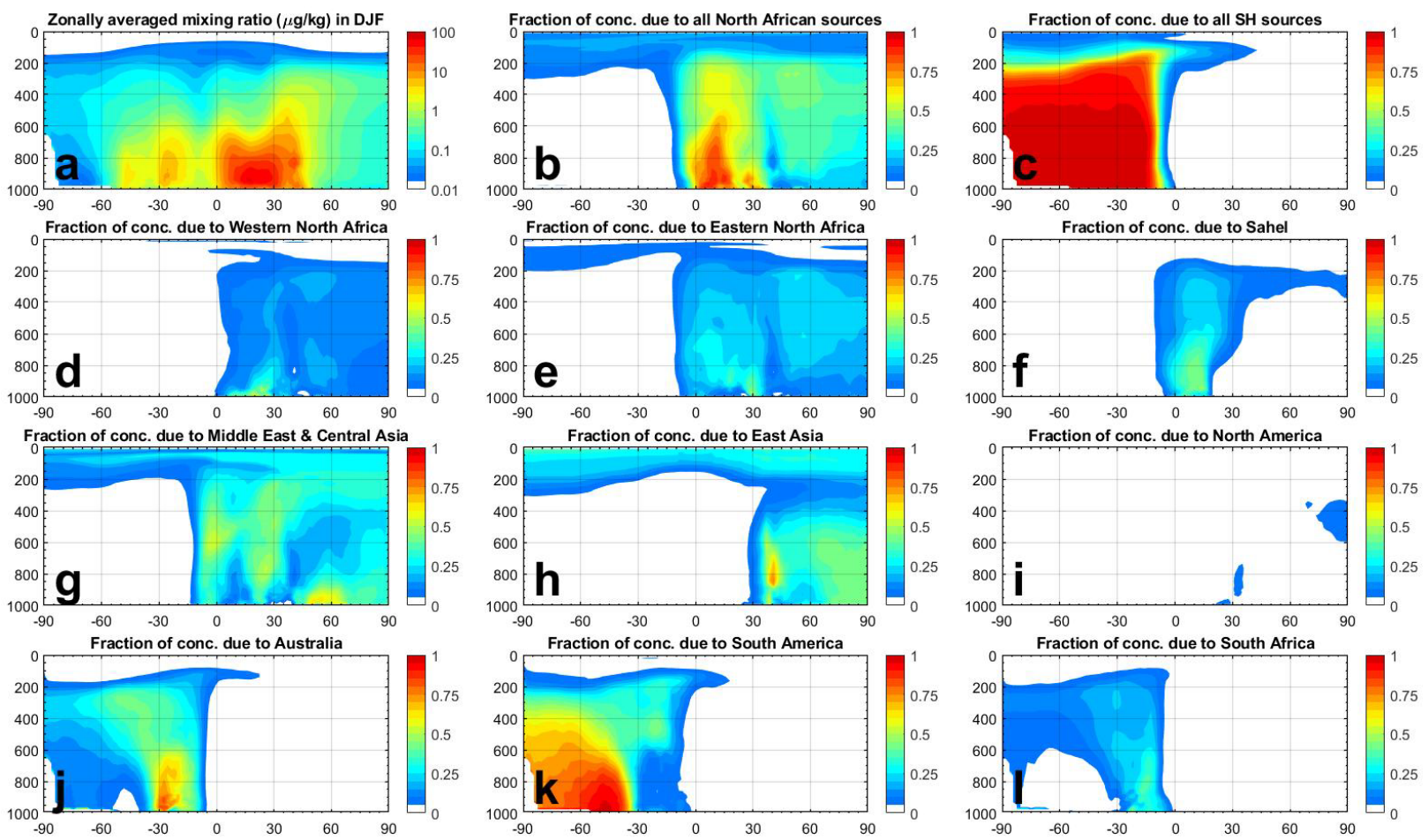

Figure S20. Attribution of the zonally averaged $\mathrm{PM}_{20}$ dust concentration to the world's main source regions in boreal Winter (DJF). Panel (a) shows the dust mixing ratio (dust concentration normalized by air density) as a 
function of latitude (horizontal axis) and pressure in $\mathrm{hPa}$ (vertical axis). Panels (b)-(l) show the partition of the dust concentration per source region, with panel ordering identical to Figures S12-S19.
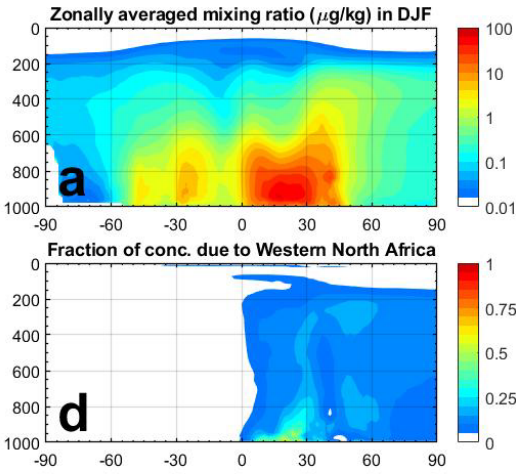

Fraction of conc. due to Middle East \& Central Asia
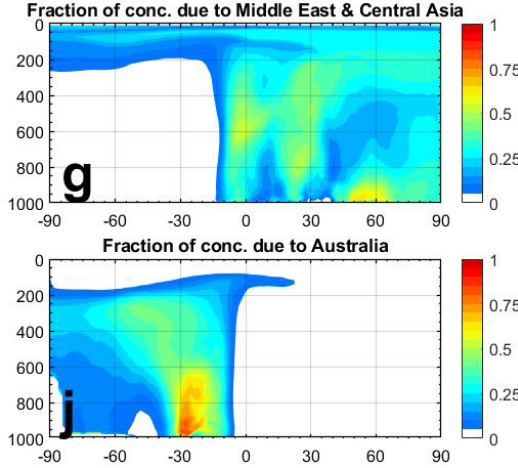
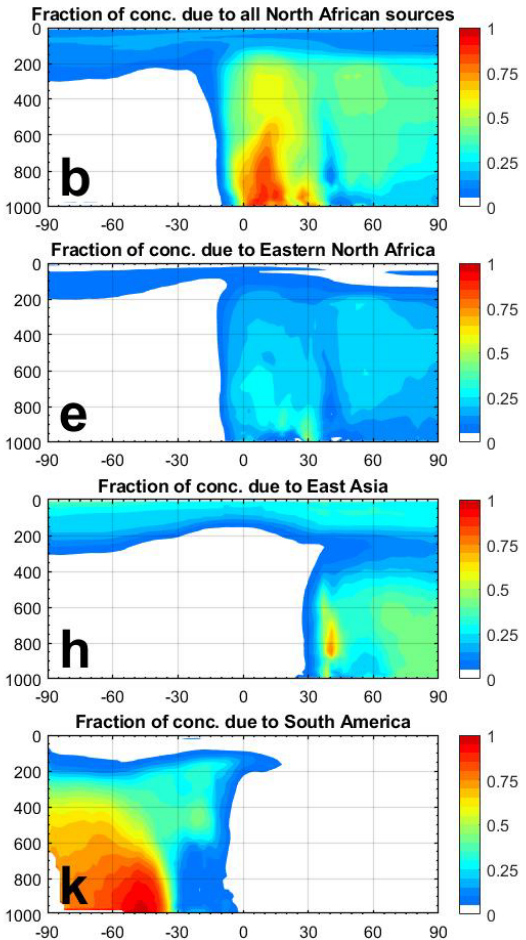
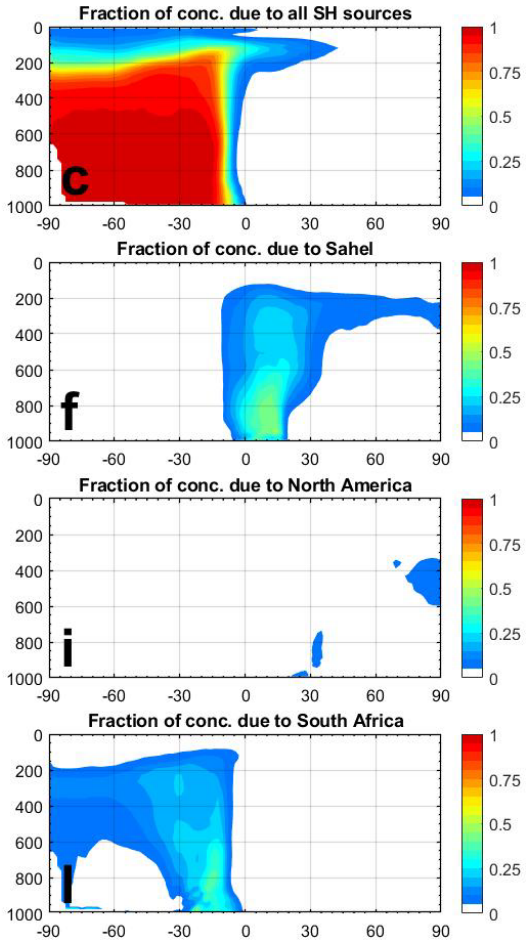

Figure S21. As in Figure S20, but for the attribution of the zonally-averaged $\mathrm{PM}_{20}$ concentration in boreal Spring (MAM).
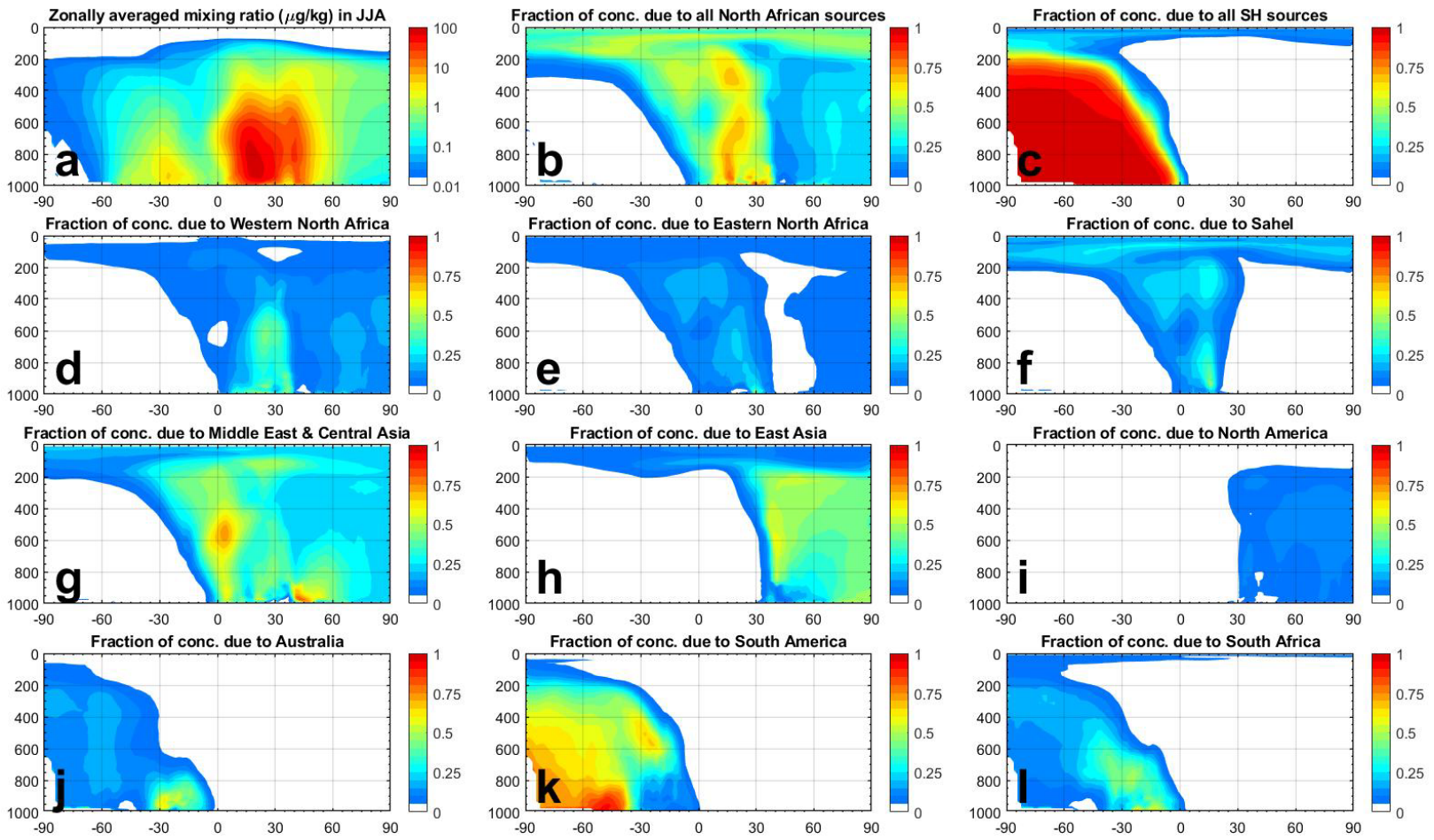

Figure S22. As in Figure S20, but for the attribution of the zonally-averaged $\mathrm{PM}_{20}$ concentration in boreal Summer (JJA). 

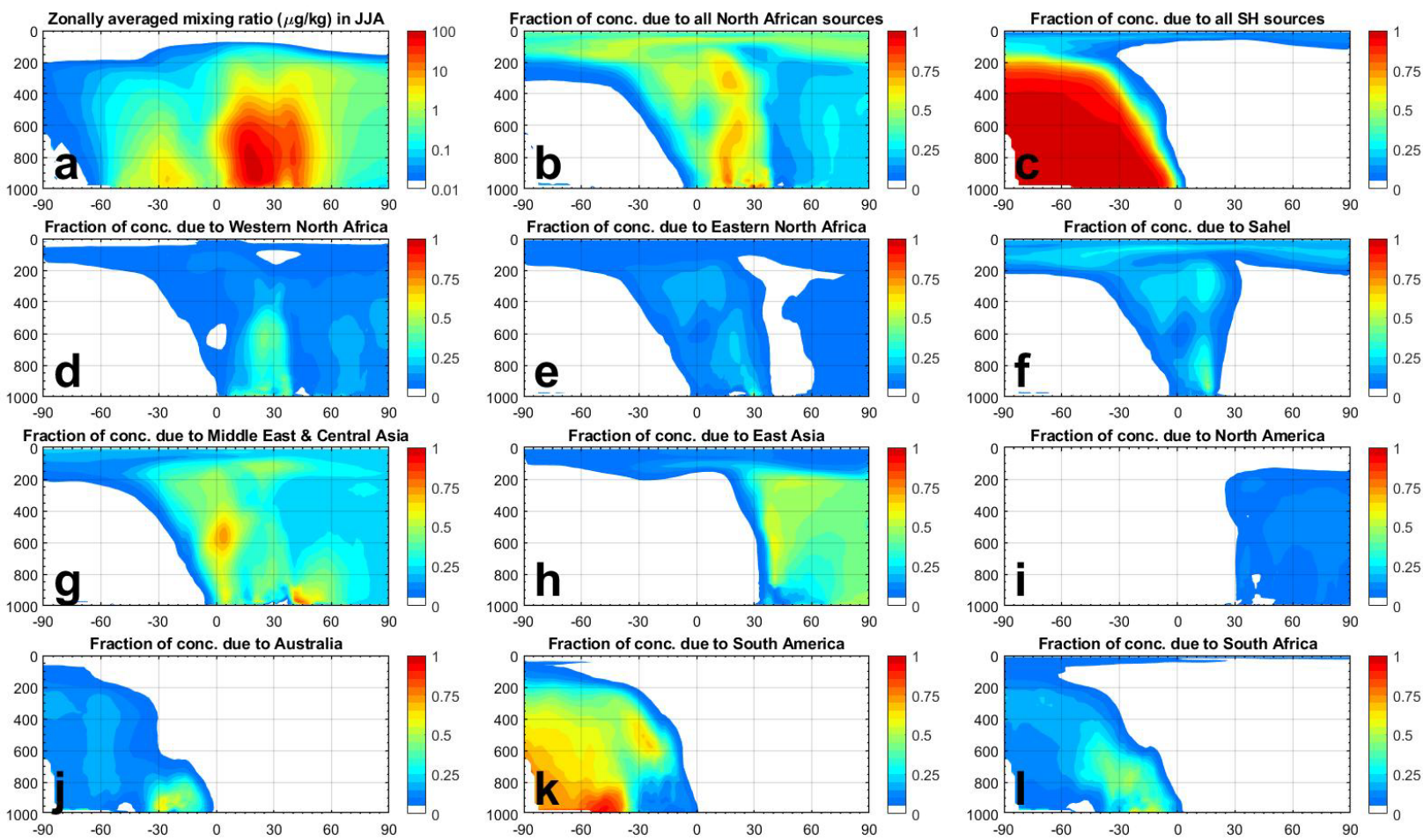

Figure S23. As in Figure S20, but for the attribution of the zonally-averaged $\mathrm{PM}_{20}$ concentration in boreal Fall $(\mathrm{SON})$.

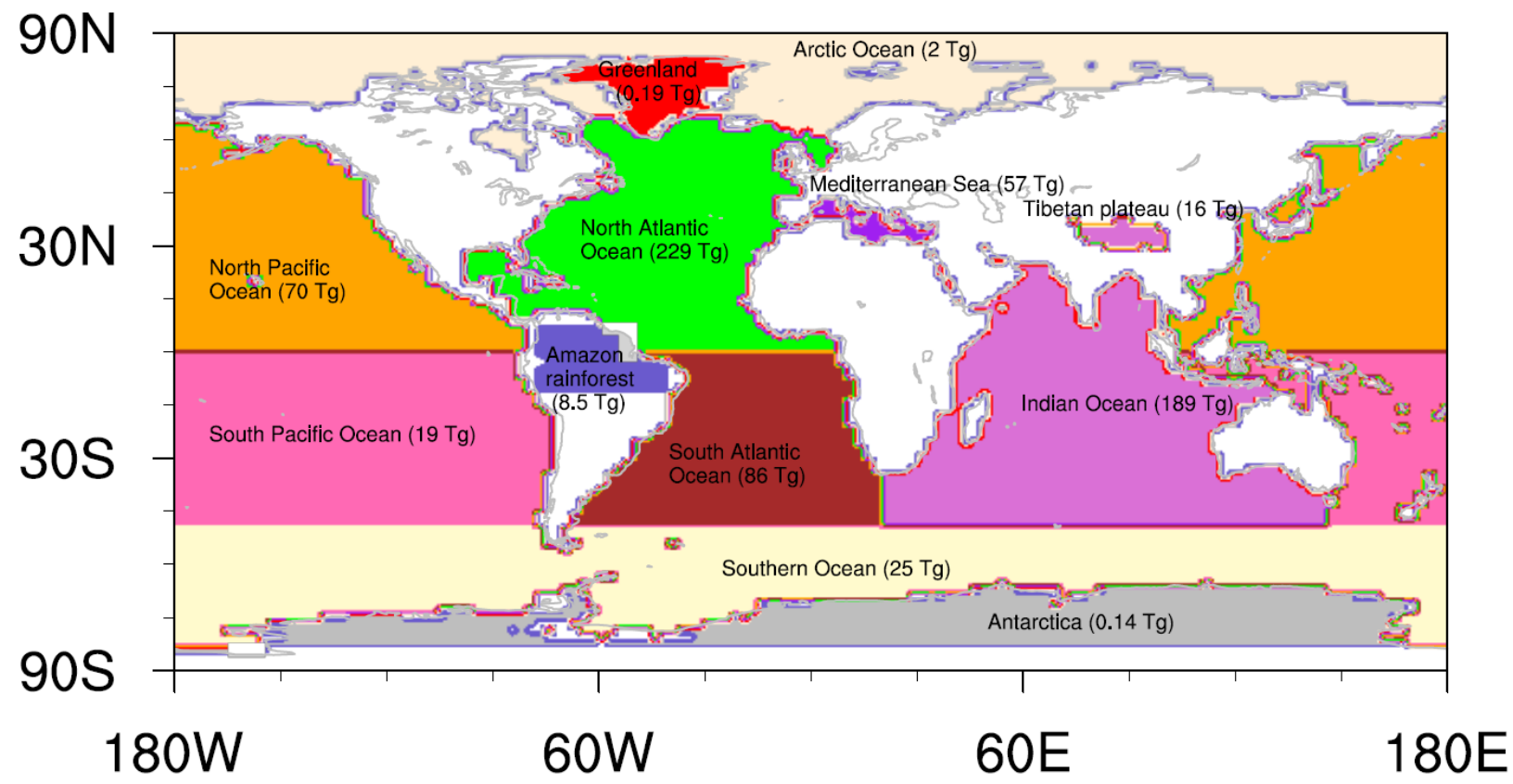

Figure S24. Map of regions to which deposition fluxes are quantified in the main text (Tables 2 and 3), which include the world's ocean basins, as well as terrestrial regions for which dust deposition is particularly important, namely the Amazon rainforest, Greenland, Antarctica, and the Tibetan Plateau. The median estimate of the annual deposition flux to each region is also noted. 

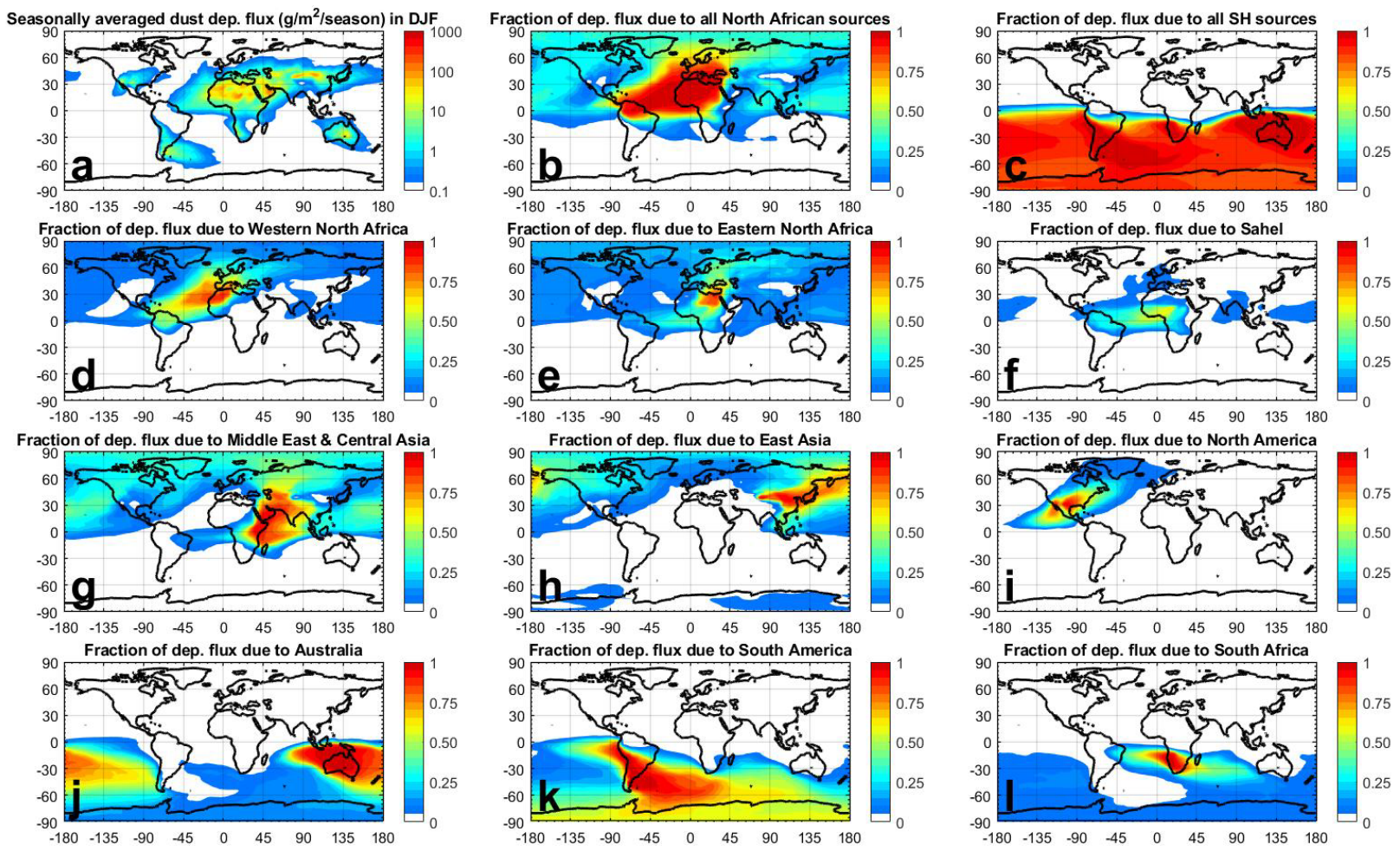

Figure S25. Attribution to the world's main source regions of the seasonally-averaged PM20 dust deposition flux in boreal Winter (DJF). Panel ordering is identical to Figures S12-S23.
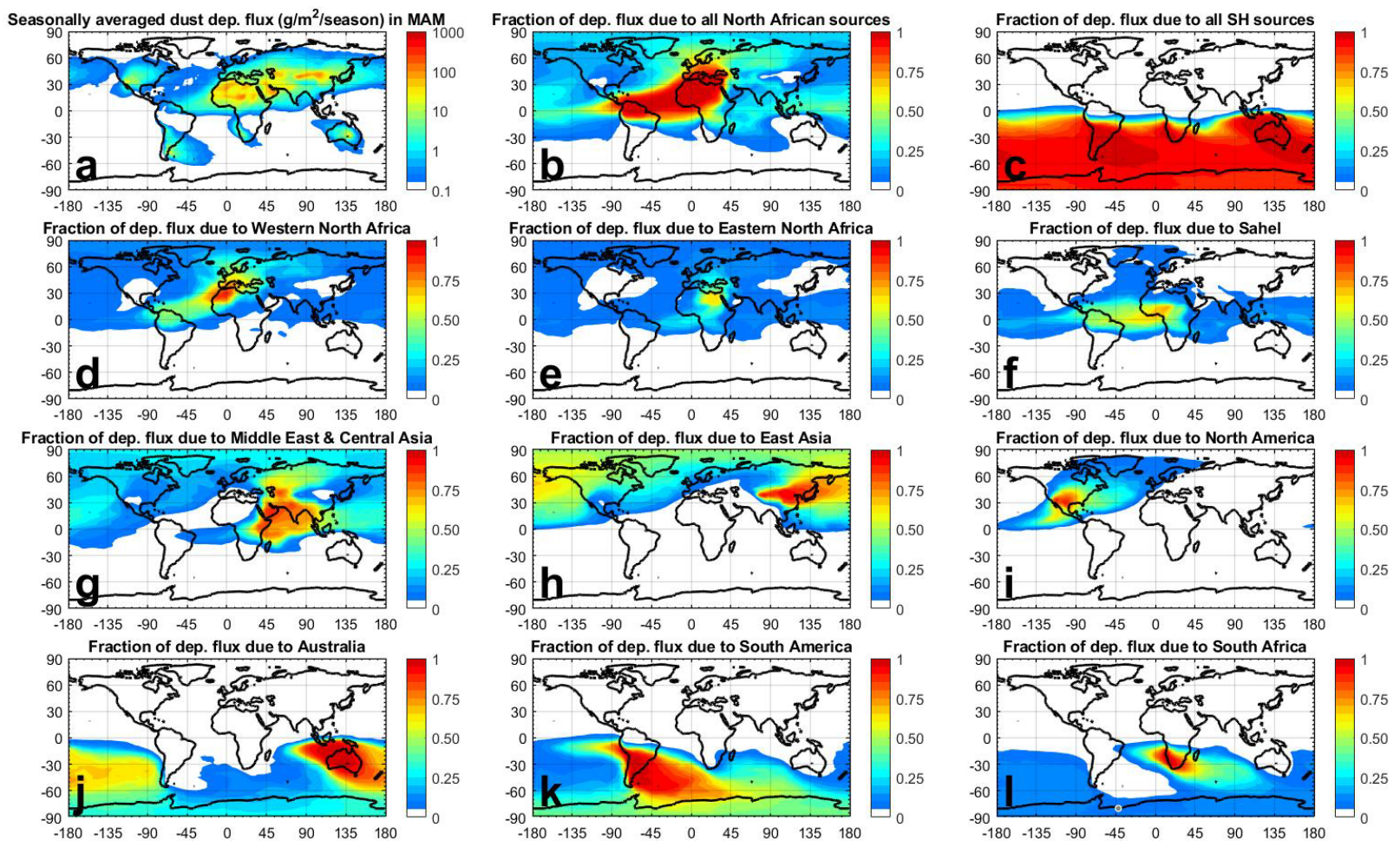
Figure S26. As in Figure S25, but for the attribution of the $\mathrm{PM}_{20}$ dust deposition flux in boreal Spring (MAM).
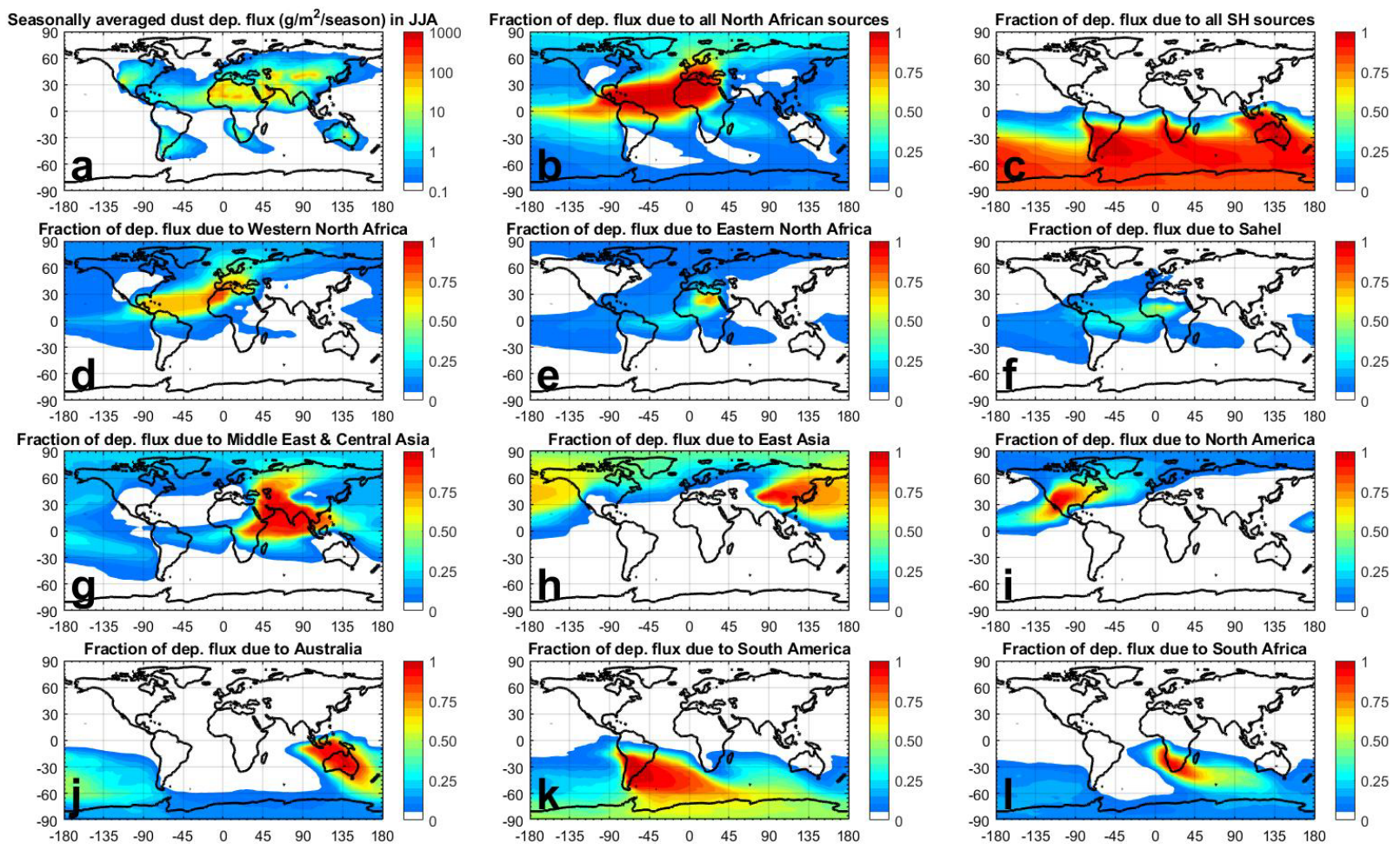

Figure S27. As in Figure S25, but for the attribution of the $\mathrm{PM}_{20}$ dust deposition flux in boreal Summer (JJA).
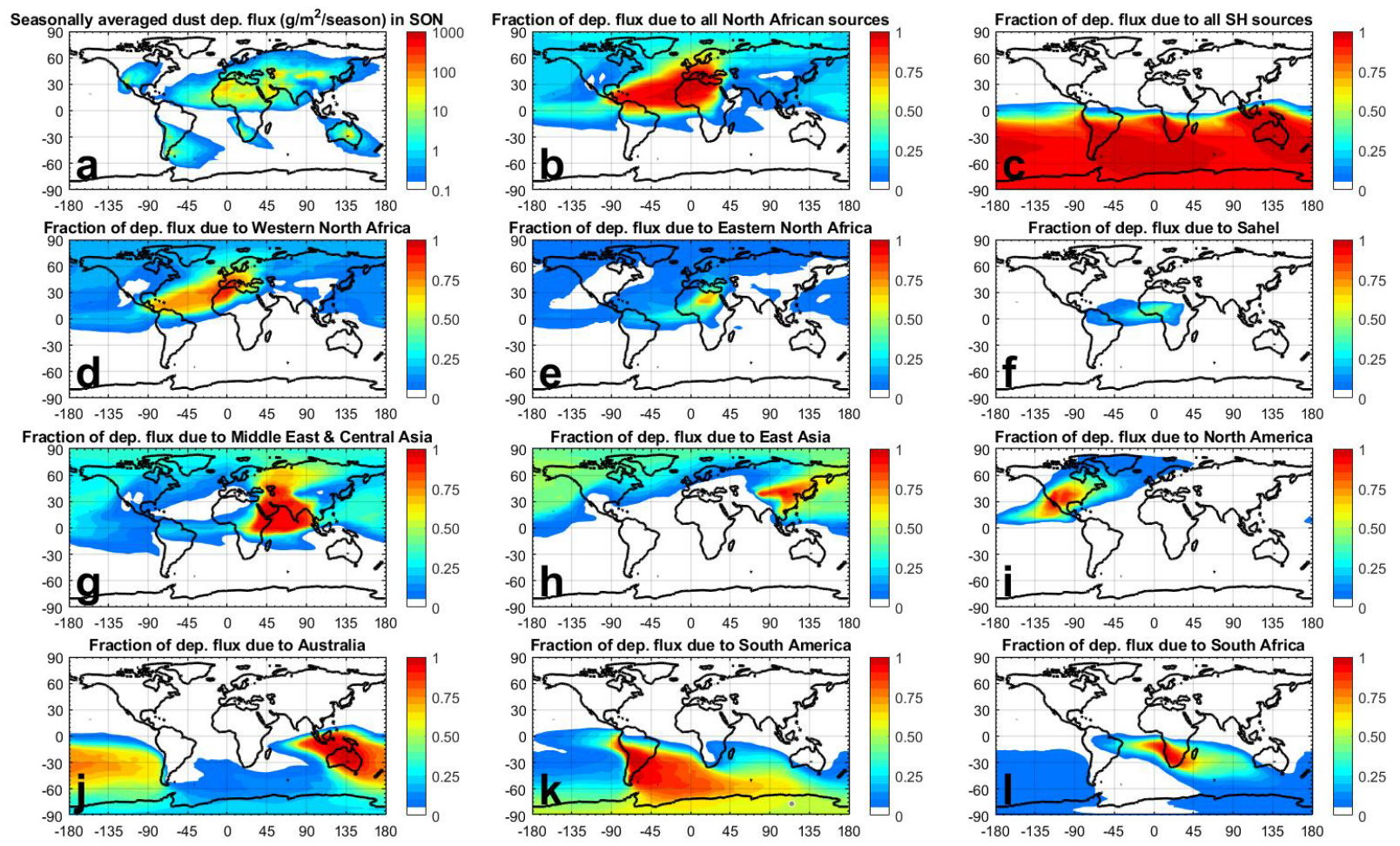
Figure S28. As in Figure S25, but for the attribution of the $\mathrm{PM}_{20}$ dust deposition flux in boreal Fall (SON).

\section{References}

Badia, A., Jorba, O., Voulgarakis, A., Dabdub, D., Garcia-Pando, C.P., Hilboll, A., Goncalves, M., Janjic, Z., 2017. Description and evaluation of the Multiscale Online Nonhydrostatic AtmospheRe CHemistry model (NMMB-MONARCH) version 1.0: gas-phase chemistry at global scale. Geoscientific Model Development 10, 609-638.

Balkanski, Y., Schulz, M., Moulin, C., Ginoux, P., 2004. The formulation of dust emissions on global scale: formulation and validation using satellite retrievals, in: Granier, C., Artaxo, P., Reeves, C. (Eds.), Emissions of Atmospheric Trace Compounds. Kluwer Academic Publishers, Dordrecht, pp. 239-267.

Bauer, S.E., Koch, D., 2005. Impact of heterogeneous sulfate formation at mineral dust surfaces on aerosol loads and radiative forcing in the Goddard Institute for Space Studies general circulation model. Journal of Geophysical Research-Atmospheres 110.

Cakmur, R.V., Miller, R.L., Perlwitz, J., Geogdzhayev, I.V., Ginoux, P., Koch, D., Kohfeld, K.E., Tegen, I., Zender, C.S., 2006. Constraining the magnitude of the global dust cycle by minimizing the difference between a model and observations. Journal of Geophysical Research-Atmospheres 111, D06207.

Cakmur, R.V., Miller, R.L., Torres, O., 2004. Incorporating the effect of small-scale circulations upon dust emission in an atmospheric general circulation model. Journal of Geophysical ResearchAtmospheres 109.

Checa-Garcia, R., 2020. FunFAN: FUNctions For Aerosol Modelling. Zenodo.

Checa-Garcia, R., Hegglin, M.I., Kinnison, D., Plummer, D.A., Shine, K.P., 2018. Historical Tropospheric and Stratospheric Ozone Radiative Forcing Using the CMIP6 Database. Geophysical Research Letters 45, 3264-3273.

Chin, M., Ginoux, P., Kinne, S., Torres, O., Holben, B.N., Duncan, B.N., Martin, R.V., Logan, J.A., Higurashi, A., Nakajima, T., 2002. Tropospheric aerosol optical thickness from the GOCART model and comparisons with satellite and Sun photometer measurements. J. Atmos. Sci. 59, 461-483.

Claquin, T., Schulz, M., Balkanski, Y.J., 1999. Modeling the mineralogy of atmospheric dust sources. Journal of Geophysical Research-Atmospheres 104, 22243-22256.

Colarco, P., da Silva, A., Chin, M., Diehl, T., 2010. Online simulations of global aerosol distributions in the NASA GEOS-4 model and comparisons to satellite and ground-based aerosol optical depth. Journal of Geophysical Research-Atmospheres 115.

Colarco, P.R., Nowottnick, E.P., Randles, C.A., Yi, B.Q., Yang, P., Kim, K.M., Smith, J.A., Bardeen, C.G., 2014. Impact of radiatively interactive dust aerosols in the NASA GEOS-5 climate model: Sensitivity to dust particle shape and refractive index. Journal of Geophysical Research-Atmospheres 119, 753786.

Dee, D.P., Uppala, S.M., Simmons, A.J., Berrisford, P., Poli, P., Kobayashi, S., Andrae, U., Balmaseda, M.A., Balsamo, G., Bauer, P., Bechtold, P., Beljaars, A.C.M., van de Berg, L., Bidlot, J., Bormann, N., Delsol, C., Dragani, R., Fuentes, M., Geer, A.J., Haimberger, L., Healy, S.B., Hersbach, H., Holm, E.V., Isaksen, L., Kallberg, P., Kohler, M., Matricardi, M., McNally, A.P., Monge-Sanz, B.M., Morcrette, J.J., Park, B.K., Peubey, C., de Rosnay, P., Tavolato, C., Thepaut, J.N., Vitart, F., 2011. The ERA-Interim reanalysis: configuration and performance of the data assimilation system. Quarterly Journal of the Royal Meteorological Society 137, 553-597.

Di Biagio, C., Balkanski, Y., Albani, S., Boucher, O., Formenti, P., 2020. Direct Radiative Effect by Mineral Dust Aerosols Constrained by New Microphysical and Spectral Optical Data. Geophysical Research Letters 47. 
Gelaro, R., McCarty, W., Suarez, M.J., Todling, R., Molod, A., Takacs, L., Randles, C.A., Darmenov, A., Bosilovich, M.G., Reichle, R., Wargan, K., Coy, L., Cullather, R., Draper, C., Akella, S., Buchard, V., Conaty, A., da Silva, A.M., Gu, W., Kim, G.K., Koster, R., Lucchesi, R., Merkova, D., Nielsen, J.E., Partyka, G., Pawson, S., Putman, W., Rienecker, M., Schubert, S.D., Sienkiewicz, M., Zhao, B., 2017. The Modern-Era Retrospective Analysis for Research and Applications, Version 2 (MERRA-2). Journal of Climate 30, 5419-5454.

Ginoux, P., Chin, M., Tegen, I., Prospero, J.M., Holben, B., Dubovik, O., Lin, S.J., 2001. Sources and distributions of dust aerosols simulated with the GOCART model. J. Geophys. Res. 106, 2025520273.

Ginoux, P., Prospero, J.M., Gill, T.E., Hsu, N.C., Zhao, M., 2012. Global-scale attribution of anthropogenic and natural dust sources and their emission rates based on MODIS Deep Blue aerosol products. Reviews of Geophysics 50, Rg3005.

Guerschman, J.P., Scarth, P.F., McVicar, T.R., Renzullo, L.J., Malthus, T.J., Stewart, J.B., Rickards, J.E., Trevithick, R., 2015. Assessing the effects of site heterogeneity and soil properties when unmixing photosynthetic vegetation, non-photosynthetic vegetation and bare soil fractions from Landsat and MODIS data. Remote Sensing of Environment 161, 12-26.

Hamilton, D.S., Scanza, R.A., Feng, Y., Guinness, J., Kok, J.F., Li, L.L., Liu, X.H., Rathod, S.D., Wan, J.S., Wu, M.X., Mahowald, N.M., 2019. Improved methodologies for Earth system modelling of atmospheric soluble iron and observation comparisons using the Mechanism of Intermediate complexity for Modelling Iron (MIMI v1.0). Geoscientific Model Development 12, 3835-3862.

Hauglustaine, D.A., Hourdin, F., Jourdain, L., Filiberti, M.A., Walters, S., Lamarque, J.F., Holland, E.A., 2004. Interactive chemistry in the Laboratoire de Meteorologie Dynamique general circulation model: Description and background tropospheric chemistry evaluation. Journal of Geophysical Research-Atmospheres 109.

Haustein, K., Perez, C., Baldasano, J.M., Jorba, O., Basart, S., Miller, R.L., Janjic, Z., Black, T., Nickovic, S., Todd, M.C., Washington, R., Muller, D., Tesche, M., Weinzierl, B., Esselborn, M., Schladitz, A., 2012. Atmospheric dust modeling from meso to global scales with the online NMMB/BSC-Dust model Part 2: Experimental campaigns in Northern Africa. Atmospheric Chemistry and Physics 12, 29332958.

Hourdin, F., Grandpeix, J.Y., Rio, C., Bony, S., Jam, A., Cheruy, F., Rochetin, N., Fairhead, L., Idelkadi, A., Musat, I., Dufresne, J.L., Lahellec, A., Lefebvre, M.P., Roehrig, R., 2013. LMDZ5B: the atmospheric component of the IPSL climate model with revisited parameterizations for clouds and convection. Clim. Dyn. 40, 2193-2222.

Hsu, N.C., Tsay, S.C., King, M.D., Herman, J.R., 2004. Aerosol properties over bright-reflecting source regions. IEEE Trans. Geosci. Remote Sens. 42, 557-569.

Huneeus, N., Schulz, M., Balkanski, Y., Griesfeller, J., Prospero, J., Kinne, S., Bauer, S., Boucher, O., Chin, M., Dentener, F., Diehl, T., Easter, R., Fillmore, D., Ghan, S., Ginoux, P., Grini, A., Horowitz, L., Koch, D., Krol, M.C., Landing, W., Liu, X., Mahowald, N., Miller, R., Morcrette, J.J., Myhre, G., Penner, J., Perlwitz, J., Stier, P., Takemura, T., Zender, C.S., 2011. Global dust model intercomparison in AeroCom phase I. Atmos. Chem. Phys. 11, 7781-7816.

Hurrell, J.W., Holland, M.M., Gent, P.R., Ghan, S., Kay, J.E., Kushner, P.J., Lamarque, J.F., Large, W.G., Lawrence, D., Lindsay, K., Lipscomb, W.H., Long, M.C., Mahowald, N., Marsh, D.R., Neale, R.B., Rasch, P., Vavrus, S., Vertenstein, M., Bader, D., Collins, W.D., Hack, J.J., Kiehl, J., Marshall, S., 2013. The Community Earth System Model A Framework for Collaborative Research. Bulletin of the American Meteorological Society 94, 1339-1360.

Ito, A., Kok, J.F., 2017. Do dust emissions from sparsely vegetated regions dominate atmospheric iron supply to the Southern Ocean? Journal of Geophysical Research-Atmospheres 122, 3987-4002. 
Ito, A., Myriokefalitakis, S., Kanakidou, M., Mahowald, N.M., Scanza, R.A., Hamilton, D.S., Baker, A.R., Jickells, T., Sarin, M., Bikkina, S., Gao, Y., Shelley, R.U., Buck, C.S., Landing, W.M., Bowie, A.R., Perron, M.M.G., Guieu, C., Meskhidze, N., Johnson, M.S., Feng, Y., Kok, J.F., Nenes, A., Duce, R.A., 2019. Pyrogenic iron: The missing link to high iron solubility in aerosols. Science Advances 5.

Janjic, Z., Gall, R., 2012. Scientific documentation of the NCEP Nonhydrostatic Multiscale Model on the B grid (NMMB). National Center for Atmospheric Research, Camp Springs, MD, USA.

Janjic, Z.I., Gerrity, J.P., Nickovic, S., 2001. An alternative approach to nonhydrostatic modeling. Monthly Weather Review 129, 1164-1178.

Kalnay, E., Kanamitsu, M., Kistler, R., Collins, W., Deaven, D., Gandin, L., Iredell, M., Saha, S., White, G., Woollen, J., Zhu, Y., Chelliah, M., Ebisuzaki, W., Higgins, W., Janowiak, J., Mo, K.C., Ropelewski, C., Wang, J., Leetmaa, A., Reynolds, R., Jenne, R., Joseph, D., 1996. The NCEP/NCAR 40-year reanalysis project. Bulletin of the American Meteorological Society 77, 437-471.

King, J., Nickling, W.G., Gillies, J.A., 2005. Representation of vegetation and other nonerodible elements in aeolian shear stress partitioning models for predicting transport threshold. Journal of Geophysical Research-Earth Surface 110.

Klose, M., Shao, Y.P., Li, X.L., Zhang, H.S., Ishizuka, M., Mikami, M., Leys, J.F., 2014. Further development of a parameterization for convective turbulent dust emission and evaluation based on field observations. Journal of Geophysical Research-Atmospheres 119.

Koch, D., Jacob, D., Tegen, I., Rind, D., Chin, M., 1999. Tropospheric sulfur simulation and sulfate direct radiative forcing in the Goddard Institute for Space Studies general circulation model. Journal of Geophysical Research-Atmospheres 104, 23799-23822.

Kok, J.F., 2011. A scaling theory for the size distribution of emitted dust aerosols suggests climate models underestimate the size of the global dust cycle. Proc. Natl. Acad. Sci. U. S. A. 108, 1016-1021.

Kok, J.F., Mahowald, N.M., Fratini, G., Gillies, J.A., Ishizuka, M., Leys, J.F., Mikami, M., Park, M.S., Park, S.U., Van Pelt, R.S., Zobeck, T.M., 2014. An improved dust emission model - Part 1: Model description and comparison against measurements. Atmos. Chem. Phys. 14, 13023-13041.

Kok, J.F., Ridley, D.A., Zhou, Q., Miller, R.L., Zhao, C., Heald, C.L., Ward, D.S., Albani, S., Haustein, K., 2017. Smaller desert dust cooling effect estimated from analysis of dust size and abundance. Nature Geoscience 10, 274-278.

Krinner, G., Viovy, N., de Noblet-Ducoudre, N., Ogee, J., Polcher, J., Friedlingstein, P., Ciais, P., Sitch, S., Prentice, I.C., 2005. A dynamic global vegetation model for studies of the coupled atmospherebiosphere system. Global Biogeochemical Cycles 19.

Marticorena, B., Bergametti, G., 1995. Modeling the atmospheric dust cycle .1. Design of a soil-derived emission scheme. Journal of Geophysical Research-Atmospheres 100, 16415-16430.

Matthes, K., Funke, B., Andersson, M.E., Barnard, L., Beer, J., Charbonneau, P., Clilverd, M.A., de Wit, T.D., Haberreiter, M., Hendry, A., Jackman, C.H., Kretzschmar, M., Kruschke, T., Kunze, M., Langematz, U., Marsh, D.R., Maycock, A.C., Misios, S., Rodger, C.J., Scaife, A.A., Seppala, A., Shangguan, M., Sinnhuber, M., Tourpali, K., Usoskin, I., De Kamp, M.V., Verronen, P.T., Versick, S., 2017. Solar forcing for CMIP6 (v3.2). Geoscientific Model Development 10, 2247-2302.

Miller, R.L., Cakmur, R.V., Perlwitz, J., Geogdzhayev, I.V., Ginoux, P., Koch, D., Kohfeld, K.E., Prigent, C., Ruedy, R., Schmidt, G.A., Tegen, I., 2006. Mineral dust aerosols in the NASA goddard institute for Space Sciences ModelE atmospheric general circulation model. J. Geophys. Res.-Atmos. 111, D06208.

Myriokefalitakis, S., Ito, A., Kanakidou, M., Nenes, A., Krol, M.C., Mahowald, N.M., Scanza, R.A., Hamilton, D.S., Johnson, M.S., Meskhidze, N., Kok, J.F., Guieu, C., Baker, A.R., Jickells, T.D., Sarin, M.M., Bikkina, S., Shelley, R., Bowie, A., Perron, M.M.G., Duce, R.A., 2018. Reviews and syntheses: the GESAMP atmospheric iron deposition model intercomparison study. Biogeosciences 15, 66596684. 
Perez, C., Haustein, K., Janjic, Z., Jorba, O., Huneeus, N., Baldasano, J.M., Black, T., Basart, S., Nickovic, S., Miller, R.L., Perlwitz, J.P., Schulz, M., Thomson, M., 2011. Atmospheric dust modeling from meso to global scales with the online NMMB/BSC-Dust model - Part 1: Model description, annual simulations and evaluation. Atmospheric Chemistry and Physics 11, 13001-13027.

Perlwitz, J.P., Garcia-Pando, C.P., Miller, R.L., 2015. Predicting the mineral composition of dust aerosols Part 1: Representing key processes. Atmos. Chem. Phys. 15, 11593-11627.

Prospero, J.M., Ginoux, P., Torres, O., Nicholson, S.E., Gill, T.E., 2002. Environmental characterization of global sources of atmospheric soil dust identified with the Nimbus 7 Total Ozone Mapping Spectrometer (TOMS) absorbing aerosol product. Reviews of Geophysics 40, 1002.

Randles, C.A., da Silva, A.M., Buchard, V., Colarco, P.R., Darmenov, A., Govindaraju, R., Smirnov, A., Holben, B., Ferrare, R., Hair, J., Shinozuka, Y., Flynn, C.J., 2017. The MERRA-2 Aerosol Reanalysis, 1980 Onward. Part I: System Description and Data Assimilation Evaluation. Journal of Climate 30, 6823-6850.

Raupach, M.R., Gillette, D.A., Leys, J.F., 1993. The effect of roughness elements on wind erosion threshold. Journal of Geophysical Research-Atmospheres 98, 3023-3029.

Ridley, D.A., Heald, C.L., Kok, J.F., Zhao, C., 2016. An observationally-constrained estimate of global dust aerosol optical depth. Atmos. Chem. Phys. 16, 15097-15117.

Rienecker, M.M., Suarez, M.J., Todling, R., Bacmeister, J., Takacs, L., Liu, H.-C., Gu, W., Sienkiewicz, M., Koster, R.D., Gelaro, R., Stajner, I., Nielsen, J.E., 2008. The GEOS-5 Data Assimilation System Documentation of Versions 5.0.1, 5.1.0, and 5.2.0, Technical Report Series on Global Modeling and Data Assimilation.

Ryder, C.L., Highwood, E.J., Rosenberg, P.D., Trembath, J., Brooke, J.K., Bart, M., Dean, A., Crosier, J., Dorsey, J., Brindley, H., Banks, J., Marsham, J.H., McQuaid, J.B., Sodemann, H., Washington, R., 2013. Optical properties of Saharan dust aerosol and contribution from the coarse mode as measured during the Fennec 2011 aircraft campaign. Atmospheric Chemistry and Physics 13, 303-325.

Scanza, R., Mahowald, N., Ghan, S., Zender, C.S., Kok, J.F., Liu, X., Zhang, Y., Albani, S., 2015. Modeling dust as component minerals in the Community Atmosphere Model: development of framework and impact on radiative forcing. Atmos. Chem. Phys. 15, 537-561.

Scanza, R.A., Hamilton, D.S., Garcia-Pando, C.P., Buck, C., Baker, A., Mahowald, N.M., 2018. Atmospheric processing of iron in mineral and combustion aerosols: development of an intermediate-complexity mechanism suitable for Earth system models. Atmospheric Chemistry and Physics 18, 14175-14196.

Schmidt, G.A., Ruedy, R., Hansen, J.E., Aleinov, I., Bell, N., Bauer, M., Bauer, S., Cairns, B., Canuto, V., Cheng, Y., Del Genio, A., Faluvegi, G., Friend, A.D., Hall, T.M., Hu, Y.Y., Kelley, M., Kiang, N.Y., Koch, D., Lacis, A.A., Lerner, J., Lo, K.K., Miller, R.L., Nazarenko, L., Oinas, V., Perlwitz, J., Rind, D., Romanou, A., Russell, G.L., Sato, M., Shindell, D.T., Stone, P.H., Sun, S., Tausnev, N., Thresher, D., Yao, M.S., 2006. Present-day atmospheric simulations using GISS ModelE: Comparison to in situ, satellite, and reanalysis data. Journal of Climate 19, 153-192.

Schulz, M., Cozic, A., Szopa, S., 2009. LMDzT-INCA dust forecast model developments and associated validation efforts. IOP Conference Series: Earth and Environmental Science 7.

Shao, Y., 2001. A model for mineral dust emission. Journal of Geophysical Research-Atmospheres 106, 20239-20254.

Shao, Y., Ishizuka, M., Mikami, M., Leys, J.F., 2011. Parameterization of size-resolved dust emission and validation with measurements. Journal of Geophysical Research-Atmospheres 116, D08203.

Shao, Y.P., 2004. Simplification of a dust emission scheme and comparison with data. Journal of Geophysical Research-Atmospheres 109, D10202.

Shao, Y.P., Lu, H., 2000. A simple expression for wind erosion threshold friction velocity. Journal of Geophysical Research-Atmospheres 105, 22437-22443. 
Shao, Y.P., Raupach, M.R., Findlater, P.A., 1993. Effect of saltation bombardment on the entrainment of dust by wind. Journal of Geophysical Research-Atmospheres 98, 12719-12726.

Shao, Y.P., Raupach, M.R., Leys, J.F., 1996. A model for predicting aeolian sand drift and dust entrainment on scales from paddock to region. Australian Journal of Soil Research 34, 309-342.

Wang, M., Penner, J.E., 2009. Aerosol indirect forcing in a global model with particle nucleation. Atmospheric Chemistry and Physics 9, 239-260.

Webb, N.P., Okin, G.S., Brown, S., 2014. The effect of roughness elements on wind erosion: The importance of surface shear stress distribution. Journal of Geophysical Research-Atmospheres 119, 6066-6084.

Wesely, M.L., Hicks, B.B., 1977. SOME FACTORS THAT AFFECT DEPOSITION RATES OF SULFUR-DIOXIDE AND SIMILAR GASES ON VEGETATION. Journal of the Air Pollution Control Association 27, 11101116.

Zender, C.S., Bian, H.S., Newman, D., 2003. Mineral Dust Entrainment and Deposition (DEAD) model: Description and 1990s dust climatology. Journal of Geophysical Research-Atmospheres 108, 4416. 